\title{
Fathers matter: Intrahousehold responsibilities and children's wellbeing during the COVID-19 lockdown in Italy
}

\author{
Lucia Mangiavacchi $^{\mathrm{a}, \mathrm{b}}$, Luca Piccoli ${ }^{\mathrm{c}, \mathrm{b}, *}$, Luca Pieroni $^{\mathrm{a}}$ \\ a University of Perugia, Italy \\ ${ }^{\mathrm{b}}$ Institute of Labor Economics (IZA), Germany \\ ${ }^{\mathrm{c}}$ University of Trento, Italy
}

\section{A R T I C L E I N F O}

\section{Article history:}

Received 24 November 2020

Received in revised form 28 April 2021

Accepted 8 May 2021

Available online 13 May 2021

\section{JEL classification:}

I21

I24

$\mathrm{J} 13$

J16

Keywords:

Parenting

Childcare

Children's education

Emotional skills

COVID-19

\begin{abstract}
A B S T R A C T
The lockdown imposed during the spring of 2020 as a result of the COVID-19 pandemic upset families lives, in addition to the health consequences of the virus, forcing parents to completely reorganize their labor, domestic work and childcare time. At the same time, school closures forced children to rearrange their lives and learning processes: in Italy, schools and nurseries were closed for four months, and the incidence and quality of distance learning activities was heterogeneous across education levels and among schools. Using real-time survey data on families with under-16 children collected in April 2020, which include information on parents' market and household work, and their perception of their children's wellbeing, we estimate how the lockdown has affected children's use of time, their emotional status and their home learning, and whether the reallocation of intrahousehold responsibilities during the lockdown played a role in this process. Changes in the parental division of household tasks and childcare, mostly induced by the labor market restrictions imposed during the lockdown, point to a greater involvement of fathers in childcare and homeschooling activities. This positive variation in fathers' involvement is accompanied by an increase in children's emotional wellbeing and by a reduction in TV and passive screen time. On the other hand, the quality of children's home learning does not appear to depend on which parent is overseeing their work, but rather on the type of distance learning activities proposed by their teachers.
\end{abstract}

(C) 2021 The Authors. Published by Elsevier B.V. This is an open access article under the CC BY-NC-ND license (http://creativecommons.org/licenses/by-nc-nd/4.0/).

\section{Introduction}

From a family perspective, the spring 2020 COVID-19 lockdown had apparent consequences on two fundamental assets of families' wellbeing: parents' work and children's education. Children were out of school, with very limited childcare possibilities and without access to group activities, team sports, or playgrounds. Parents were attempting to work remotely while caring for children at the same time. In Italy, the situation was particularly severe since the country was in an almost complete lockdown from March 8 to May 3 , while some regions and municipalities started as early as February 21. Italy was the first country in Europe to close schools and nurseries (March 4, 2020). Step-wise reductions of limitations started on May 4, yet a comprehensive reopening of economic activities and traveling options across regions only began on June

\footnotetext{
* Corresponding author.

E-mail addresses: lucia.mangiavacchi@unipg.it (L. Mangiavacchi), luca.piccoli@unitn.it (L. Piccoli), luca.pieroni@unipg.it (L. Pieroni).
}

15, delaying the return to school to September 14 for most regions, i.e. after the three-month long summer vacation.

The impact of the lockdown on children's educational progress (Engzell et al., 2021; Grewenig et al., 2020) is likely to have been particularly strong in the Italian context, which is characterized by high educational inequality among socioeconomic groups (Brunello and Checchi, 2005) and regions (Angrist et al., 2017), with schools, teachers and parents substantially unprepared to manage a distance learning educational model. Schools suffered from underdeveloped IT infrastructure, lacking PCs both in classes and for teachers, most of whom were not trained in the use of computer-based or web-based educational instruments. In this context, parents struggled to cope with work, either because they were no longer able to work or because they were limited to teleworking solutions, while having to take care of children and the home without external help. Social distancing limitations imply that most working parents could not take advantage of any form of childcare, such as babysitting or grandparents, the latter being one of the pillars of the Italian childcare system.

The current paper studies how parents reacted to the lockdown in terms of gender distribution of housework and childcare ${ }^{1}$ and 
analyzes, for the first time, how these changes affected children's emotional wellbeing, educational outcomes, and use of time according to their parents. To address these research questions, we use data collected on a sample of families with children from April 7 to May 3 (in the middle of the most restrictive Italian lockdown period, "Phase I") and estimate household and child fixed-effect models.

This paper offers several contributions to the existing literature. First, we contribute to the growing literature on the changes in market and household work during the COVID-19 crisis by examining the effects of those changes on children under age 16. Alon et al. (2020) and Hupkau and Petrongolo (2020) predicted that a number of fathers would temporarily become the main caregivers and that this temporary change could lead to shifts in gender social norms. A number of studies have already tested this hypothesis in different countries affected by the COVID-19 pandemic between March and April, confirming the prediction. Amuedo-Dorantes et al. (2020) show that in the United States school closures reduce labor supply of mothers more than fathers. Del Boca et al. (2020) for Italy and Farré et al. (2020) for Spain analyzed the gender division of household tasks and childcare and found that most of the additional household workload due to the COVID-19 crisis fell on women's shoulders, with very limited contributions from their partners. On the other hand, childcare activities were more equally shared during the lockdown, especially when mothers continued to work away from home. Sevilla and Smith (2020) focused on childcare in UK families with young children and also found that the gender gap in childcare was smaller during the lockdown. We also observe a substantial increase in fathers' involvement in childcare and estimate whether this variation is associated with a differential impact of the lockdown on children's wellbeing. This temporary shift in gender roles is particularly interesting in Italy, a country characterized by persistent gender gaps and very low involvement of fathers in raising children (Bloemen et al., 2010; Barigozzi et al., 2020). We bring forward this stream of literature by further studying how household tasks temporary reallocation due to the spring 2020 lockdown may impact on children's outcomes. This is perhaps the main contribution of the present study.

Second, we offer some evidence supporting the importance of fathers' involvement in child development as already analyzed in the literature on maternal employment (Harris et al., 1998; Hsin and Felfe, 2014) and in the literature on the intergenerational transmission of attitudes and behaviors (Giménez-Nadal et al., 2019; Pieroni and Lanari, 2018). Exploiting the exogenous shock generated by the first generalized lockdown in spring 2020, we analyze the impact of the increased participation of fathers in childcare activities on how parents perceive their children's wellbeing. More specifically, we analyze how parents perceived changes in their children's emotional status, use of time and educational progress with the lockdown at large and, more specifically, how these changes were related to fathers becoming the main caregivers.

Third, we contribute to the stream of literature that considers the role of parental inputs and the allocation of time on children's cognitive and non-cognitive development (Fiorini and Keane, 2014; Del Boca et al., 2017; Mangiavacchi and Piccoli, 2018; Moroni et al., 2019). The lockdown left children with limited and fragmented educational inputs from schools, with parents also taking up the role of teachers. Overall, most children spent much less time in educational activities, thus we evaluate how children

\footnotetext{
${ }^{1}$ In Italy, intrahousehold responsibilities follow traditional gender norms, with women bearing the main responsibility of household production and childcare tasks (Barigozzi et al., 2020).
}

reallocated this time and test the mediating effects of parental inputs.

Finally, our analysis offers evidence on how school closures affected children's educational progress. This is especially relevant for Italy, where schools remained closed for four months and the reopening process was delayed until September 2020. The lockdown situation had the potential to widen educational inequalities in a manner similar to what has happened in other contexts in which schools have remained closed for a long period due to other kinds of shocks or policy changes (see for instance Jaume and Willén, 2019; Pischke, 2007). We identify the potential detrimental effect of the lockdown on their education progress, focusing on how well parents could support children in their homeschooling experience.

In our sample, we observe that more mothers than fathers completely stopped working during the lockdown (28\% vs $25 \%$ ), but as men worked more hours on average before ( 37 vs $25 \mathrm{~h}$ per week), they had more additional hours to spend on childcare, while at the same time, grandparents and babysitter hours fell to approximately one-third of their pre-lockdown value. This causes an overall small average reduction in women's share of childcare tasks, but with notable heterogeneity. In fact, the share of households in which the father is the main caregiver increases by 6.6 percentage points to almost $35 \%$ of families: a significant variation that could have an impact on children's emotional wellbeing, the quality of their use of time and their home learning process. By estimating household and child fixed-effect models, we find that the increase in fathers' involvement in childcare and homeschooling during the lockdown is accompanied by an improvement in children's emotional status, relationship with parents and a reduction in TV hours. On the other hand, parents had difficulties in accomplishing their teaching role, and the quality of children's home learning process is mostly determined by the distance learning activities offered by the schools.

The rest of the paper is organized as follows. Section 2 sets the analysis within the institutional setting and the existing empirical research. Section 3 describes data and the empirical strategy. Section 4 presents and discusses the results, and Section 5 concludes.

\section{Background}

\subsection{Institutional setting: the Italian COVID-19 lockdown}

In Italy, the first two cases of COVID-19 were identified on January 30, 2020, in Rome, and the Italian government declared a state of emergency, suspending flights from China the following day. By February 21, 79 cases had already been identified, most of which were concentrated in specific municipalities of the Lombardy (54 cases) and Veneto (17 cases) regions. On the following day, the number of recognized cases almost doubled to 152. This was the real start of the pandemic in Italy. ${ }^{2}$

The government's initial attempt to contain the pandemic started with the complete lockdown of schools, economic activities and transportation in 10 villages in Lombardy and 1 in Veneto, including prohibition to travel to/from these municipalities, applied on February 23. Immediately afterwards, several northern regions suspended school activities and public events for one week, with the possibility of extending the date according to the evolution of the pandemic. In a very rapid escalation on March 4, the government suspended all schools and sport activities at

\footnotetext{
2 Most of the data are drawn from the Italian Ministry of Health, through its daily news, with additional data provided by the Civil Protection Department at http://
} www.protezionecivile.gov.it. 
national level, and a few days later, on March 9, Italy was set under a full lockdown, forbidding individual movements unless driven by necessity (health, work, purchasing food or medicines), and on March 11, the closure of most retail shops except grocery shops and pharmacies was imposed. The complete lockdown was set on March 22/23, when all non-essential production activities were closed and any transfer outside the municipality of domicile was forbidden (except for health, work or absolute urgency reasons). Briscese et al. (2020) show that while the government communication strategy may have been suboptimal to maximize compliance with the restrictions imposed, at least half of the population complied with all restrictions, while a very small proportion did not follow any of the government's indications (less than 3\%). All these restrictions were in place until May 3, when "Phase I" ended and a gradual weakening of these restrictions was planned. This complete lockdown period is the object of this study, as a relevant share of the adult population was forced to temporarily stop working and children remained at home, without the possibility of moving from the house of domicile and without any use of external childcare service other than co-resident adults.

\subsection{Related empirical research}

Several studies have already analyzed the evolution of time allocation within the household during the lockdown following the first COVID-19 outbreak in spring 2020.

In the early period of the pandemic in Europe, Alon et al. (2020) and Hupkau and Petrongolo (2020), using pre-existing survey data for the US and UK, predict that women would take on more of the household and childcare responsibilities due to the impossibility to use formal (schools and nursery) and informal (grandparents or babysitter) childcare. Nevertheless, these studies point out that a relevant proportion of fathers would be forced to become primary caregivers if their wives were still working and they were not. Hopefully, this temporary change due to the lockdown measures would turn out to be persistent, leading to a shift in social norms. Successive studies confirmed these initial predictions by collecting and analyzing real-time data during the COVID-19 pandemic in the US, UK, Germany, Spain and Italy (Adams-Prassl et al., 2020; Andrew et al., 2020a; Biroli et al., 2020; Del Boca et al., 2020; Farré et al., 2020; Sevilla and Smith, 2020).

Farré et al. (2020) show that, in a representative sample of Spanish households, while men only increased their participation in household chores slightly, the increase in childcare needs (from 48 to $60 \mathrm{~h}$ of childcare done by parents in a week) was absorbed by both mothers and fathers. Sevilla and Smith (2020), making use of real-time data collected in the UK, find that the allocation of additional hours of childcare has become more equal than the previous allocation of childcare. The gender childcare gap has narrowed from 30.5 percentage points to 27.2 percentage points. They also document that this increase has been driven by families in which men were working from home or, to a greater extent, where men have stopped working.

In Italy, the baseline situation is particularly unequal; Barigozzi et al. (2020) document that mothers with young children perform a total amount of $60 \mathrm{~h}$ of work per week ( $25 \mathrm{~h}$ of paid work and $35 \mathrm{~h}$ of housework and childcare), while their male partners provide $47 \mathrm{~h}$ per week (a gender gap of $13 \mathrm{~h}$ per week). Del Boca et al. (2020), using a representative sample of working women interviewed at the end of April 2020, find that the additional housework associated with the lockdown has fallen on women, while childcare and home learning activities have been more equally shared. They find that $68 \%$ of women and $40 \%$ of men have spent more time on housework and childcare during the lockdown in the general sample. However, restricting the sample to families where only women continue to go to their usual place of work and their partner does not work at all, the share of husbands who performed more household tasks increased to $58 \%$ for housework (vs $61 \%$ of wives) and $54 \%$ for childcare (vs $31 \%$ of wives).

In the current paper, we focus on couples with children in Italy and are able to identify families in which fathers became the primary caregivers. Taking the analysis one step forward, we then estimate how this evolution in childcare responsibilities affected children's emotional status, time use and home learning progress.

\section{Data and empirical strategy}

\subsection{Survey and data description}

In such a worrying context, we developed a web survey specifically aiming at analyzing how Italian families reacted to the COVID-19 lockdown, collecting data right in the middle of the lockdown crisis (during the second month of the Italian "Phase I" of the lockdown). Access to and completion of the survey has been proposed on a voluntary base. The questionnaire was completely anonymous and there were no rewards for participation to the study. A total of 3352 families completed the surveys from April 7 to May 3, with most of the advertising campaign conducted on Facebook. $^{3}$ The survey was conducted without a sampling strategy; thus the data are not representative of the Italian population. Nevertheless, due to the relevant sample size and the ability to reach all Italian regions and different socioeconomic groups, as reported in Table A1, several key variables used in the analysis are in line with national statistics reported by ISTAT (the Italian National Institute of Statistics). Regarding the number of children for couples, our sample slightly over-represents couples with 2 children, at the expenses of couples with 1 child or with 3 or more children. In terms of geographical distribution, an overrepresentation of northern and central Italy is observed, although southern regions were much less affected by COVID-19, and thus it was expected that we would have lower response rates. Perhaps the most relevant difference concerns the proportion of individuals with a university degree, which was double the national average for a similarly aged population group. A significantly larger share of individuals are working and individuals of non-Italian nationality are under-represented. ${ }^{4}$ Nevertheless, the key variables of interest, i.e., couple's division of housework and childcare and children's hours of TV and reading, are very much in line with national statistics, except hours of reading, which are larger in our sample.

The survey asked for detailed information about respondents' previous and current work arrangements and on the division of household tasks, asking respondents to report their own and their partner's previous and current employment, sector of employment, labor supply evolution and hours of teleworking. The survey contained a section on couples' division of housework and childcare tasks. It collected detailed information on respondents' background characteristics including gender, age, highest level of education, marital status, and number of children below 16 , and a

\footnotetext{
3 The advertising campaign was targeted towards Italian residents in working age living with a partner, both with or without children. Facebook seemed an adequate platform to conduct the campaign as about 93\% of the Italian population aged 25-54 is active on Facebook, with a good gender balanced, as $50.6 \%$ of users are men (source: NapoleonCat stats, based of Facebook advertising API). In the advertising campaign, we acknowledged that the survey was part of a scientific research project to collect data on how families - especially children - managed to run their life under the lockdown. People may had the feeling that their contribution to a scientific research could be important in such a critical situation and for this reason we obtained a good response to the call, but also probably determined a selection of respondents towards educated mothers.

4 To check that such differences do not drive our main results, as a robustness check we replicate the analysis applying post-stratification weights calibrated on the population values of all these variables. See Section 4.3 for more details.
} 
specific section on children and on homeschooling during the lockdown. For individuals with children up to 16 years old living in the household, we asked about the number of hours spent on active childcare and on homeschooling and their evolution with the lockdown. The last section collected detailed information on each child based on his/her age and school grade. In particular, we asked questions on time use and its evolution (hours spent studying, performing extracurricular activities, reading and watching TV/passive screen/social networks), parents' subjective opinions on the child's educational progress, emotional status, parentchild relationship, whether and which type of e-learning technology their teachers have adopted, availability of computers/tablets, and so on. ${ }^{5}$

To analyze how the COVID-19 lockdown modified the family division of childcare responsibilities and, in turns, children's emotional and educational wellbeing, we use a sample of 2101 households, which include 3619 children under $16 .{ }^{6}$ The descriptive statistics of household level variable are presented in Table A2, while those that are child specific are presented in Table A3.

The descriptive statistics reported in Table A2 highlight how the family organization changed during the lockdown: mothers' share of housework was more than $75 \%$ before the lockdown and decreased to $71 \%$ during the lockdown, a reduction of 4.4 percentage points. A similar pattern is observed for the mothers' share of childcare, which decreased by 2.2 percentage points from $68.9 \%$ to $66.7 \%$. Although the reduction was smaller, the proportion of fathers that became the main caregiver, i.e., that carried out at least $50 \%$ of childcare tasks, rose substantially from $28.1 \%$ to $34.8 \%$. Approximately $28 \%$ of mothers and $25 \%$ of fathers completely stopped working (smart workers were not included in these figures) during the lockdown. As their average daily hours of work shrunk approximately by $1.4 \mathrm{~h}$ for mothers and $1.6 \mathrm{~h}$ for fathers, this reduction was almost completely determined by the exogenous suspension of their work activity that was determined by the government, not by their choice. This boosted the daily hours available for housework and/or childcare, as highlighted by the couple's amount of hours spent doing homework with their children, which rose from 3.1 to $6.5 \mathrm{~h}$ per week. In contrast, as expected, both grandparents' and babysitters' hours of childcare fell to approximately one third of their pre-lockdown values. These are also exogenous variations, as induced by the lockdown and not by family choices. During the first pandemic outbreak, a relatively modest share of the sample was under strict lockdown, either because they were COVID positive or in contact with a positive case (3\% of mothers and $1.8 \%$ of fathers).

Regarding time-invariant characteristics, we observe that prior to the lockdown, mothers contributed to $34 \%$ of family income, were on average 41 years old, had a university degree in approximately $37 \%$ of cases, and were those who responded most often to the survey ( $93 \%$ of respondents are female). ${ }^{7}$ Fathers were only slightly older (nearly 44 years old) and were more educated (almost 59\% had a university degree). More than half of the sampled households had 2 or more children (55\%), and

\footnotetext{
5 The English translation of the questionnaire for Italy is available as supplementary material.

6 The large sample reduction is mainly due to selecting only families with children, which reduced the family units by about 1000 . The sample is further reduced by about 200 units because mono-parental families were also excluded. The remaining drops in sample size are due to missing values in the variables used in the regressions, which are generally modest in magnitude.

7 The fact that such a large proportion of respondents is composed by women, is mostly due to the contents of the Facebook advertising campaign, which stressed the aspects of family life and child wellbeing. In fact a similar survey conducted in France reports $89.3 \%$ of respondents being women (Champeaux et al., 2021). Similarly data collected in Spain, Germany and Austria, which however did not focus on children, report 75-78\% of female respondents (Farré et al., 2020).
}

approximately $12 \%$ of them had other adults living in the same dwelling. Only $1.5 \%$ of the sample is composed of parents of foreign nationality.

Table A3 describes the observed variations implied by the lockdown for child level variables. Parents have observed an overall reduction in their children's emotional wellbeing. Recalling that categories take values 0 for unchanged in a -2 to 2 scale, the average value of -0.59 seems to suggest a significant reduction. At the same time, we observe a slight improvement in their personal relationship with their children (about 0.2 ). As approximately $50 \%$ of mothers and $70 \%$ of fathers were still working during the lockdown (either physically because working in a sector of national interest or because shifting to smart working), we observe an increase of 1.5 daily hours of TV, passive screen time or social network use. An increase is also observed for reading time, but by a much smaller amount, just approximately 15 min per day. In terms of educational progress, parents evaluate it as largely insufficient, with 4.8 on a scale from 0 to 10 .

A particularly relevant variation in children's activities due to the COVID-19 lockdown is the reduction in extracurricular activities, which decreased by almost half an hour per day. The average age of the children of interviewed couples is 7, where $50.7 \%$ of them are males who spent an average of $1.2 \mathrm{~h}$ per day on live online classes. $37.5 \%$ of children attend kindergarten, $40.3 \%$ primary school, and the remaining were in secondary-level education, either middle school or the first two years of high school.

\subsection{Empirical strategy}

The empirical analysis is conducted in two steps. In the first step the focus is on how the lockdown modified household division of work, using 3 indicators as dependent variables in the regression analysis: (i) the share of housework tasks carried out by women; (ii) the share of childcare carried out by women; and (iii) whether the father is the main child caregiver, a dummy variable taking the value of 1 when the father carries out at least $50 \%$ of the childcare tasks. Each of these variables is available before and during the lockdown, allowing us to perform fixed-effect regressions of the form:

$S_{h t}=\beta X_{h t}+L D_{t}+\gamma L D_{t} \cdot W_{h}+u_{h}+e_{h t}$,

where $S_{h t}$ is the selected outcome for household $h$ at time $t$ (two time periods: before and during the lockdown), $X_{h t}$ is a set of timevarying regressors and $W_{h}$ is a set of time-invariant regressors. $L D$ is to be interpreted as the residual effect of the lockdown on the dependent variable after controlling for covariates, while the $\gamma$ coefficients are to be interpreted as the differential effects of the lockdown depending on the values taken by time-invariant characteristics $W_{h}$. The parameters of Eq. (1) are estimated using a first difference estimator, specified by taking first differences of Eq. (1):

$\Delta S_{h}=L D+\gamma W_{h}+\beta \Delta X_{h}+e_{h}$,

where $L D$ corresponds to the constant and is to be interpreted as the residual impact of the lockdown on the change in the outcome. Parameters $\gamma$ are the differential impact of the lockdown for households with specific characteristics, $W_{h}$, and $\beta$ represent the impact of the variation of explanatory variables $X_{h}$.

The main aim of this first step is to verify whether the main driver of changes in the household division of work is the work status of both parents, which accounts for the fact that during the lockdown, everyone except those working in sectors of special national interest had to temporarily stop working by law. This would translate into an exogenous increase in the time available to 
perform household tasks by those who stopped working. For this reason, at variance with Del Boca et al. (2020), parents that switched to smart-working arrangements are considered to be still working during the lockdown. While it is true that in some cases, smart working may allow flexible arrangements, anecdotal evidence suggests that such experience has been frustrating and stressful since most smart workers had to accommodate a fulltime job schedule. In addition, considering childcare tasks performed as a secondary activity while working would imply very little value added for the children since parents' time would be mostly passive. Another potentially relevant factor for explaining the variation in the division of household tasks is the reduction of childcare time by grandparents and babysitters: during the lockdown, there was a sharp reduction in such hours since babysitters were not allowed to work (unless already living in the same household) and grandparents were not allowed to travel to visit the family (again unless already living in the same household).

The main explanatory variables included in $X_{i t}$ are whether the mother, the father, or both stopped working, whether the mother switched to smart working, i.e. whether she increased the hours of smart working with respect to the pre-lockdown situation, ${ }^{8}$ and the variation in the hours of work of both parents (including hours of smart-working). In addition, we also include the variation in childcare hours both by grandparents and babysitter.

The time-invariant characteristics $W_{i}$ include: the share of family income earned by the woman before the lockdown (as a proxy for her bargaining power within the household), the age of both partners and its difference, the gender of the respondent, the number of children (as a dummy indicating whether 2 or more children are present), the presence of other adults in addition to parents in the household, whether parents have a university degree and whether both parents have non-Italian nationality. As the COVID-19 pandemic had a very heterogeneous geographical spread, we included a province-specific lockdown effect (province FE). As the duration of the lockdown may have worsened some outcomes, we included the date of interview as a time trend. Finally, as the prime minister typically made a speech to the population on Friday nights, updating the status of the pandemic and indicating whether changes in the restrictive policies were to be expected in the following days, we include specific lockdown effects for the day of the week in which the survey was completed also. Standard errors of the regressions are clustered at the province level. $^{9}$

The second step, the core of our analysis, aims at analyzing how such a change in the division of household tasks affected children. For the analysis of children's outcomes $Y_{i t}$, we rely on 5 indicators: (i) the evolution in the emotional status of the child ${ }^{10}$; (ii) the evolution in the personal relationship that the child had with parents (with the same categories of emotional status); (iii) the daily hours spent by the child watching TV, passive screen time (YouTube and similar) and social media; (iv) the daily hours spent by the child reading (or listening to an adult reading for the younger kids); and ( $v$ ) an evaluation of the educational progress of

\footnotetext{
${ }^{8}$ A similar variables for fathers is not included because very few of them switched to smart working in the early lockdown period, less than $1.6 \%$ vs $14 \%$ of mothers.

${ }^{9}$ In Italy there exist 107 provinces, and they represent the smallest territorial administrative units above municipalities. The number of clusters exceeding the 50 minimum threshold commonly considered to be safe for computing clustered standard errors.

${ }^{10}$ The categorical variable takes the following values: -2 for "substantially worsened"; -1 for "slightly worsened"; 0 for "unchanged", 1 for "slightly improved"; and 2 for "substantially improved".
}

the child. ${ }^{11}$ Similarly to Eq. (1), each of these variables is available as a time variation, allowing us to perform fixed-effect regressions:

$Y_{i t}=\beta X_{i t}+L D_{t}+\gamma L D_{t} \cdot W_{i}+u_{i}+e_{i t}$,

Here, regressions are conducted at the individual rather than household level, thus since many families have more than one child, standard errors are clustered at the household level (although the alternative of clustering at the province level has barely any effect on standard errors). Apart from this, the analysis is conducted in similar way to Eq. (2), i.e.

$\Delta Y_{i}=L D+\gamma W_{i}+\beta \Delta X_{i}+e_{i}$.

The main explanatory variables included in $x_{i t}$ are those describing the parental division of household work, that is whether the father is the main child caregiver and the share of housework carried out by the mother, but also the increased amount of productive time -in a human capital perspective- that parents spend with their children, and the hours of distance learning live classes offered by the teachers. Other time-varying variables included whether both parents stopped working during the lockdown, whether the mother switched to smart working, and the variation in the hours of extracurricular activities.

The other time-invariant explanatory variables included in $W_{i}$ are: the ours of live online classes for each school level attended (kindergarten, primary or secondary), gender and age of the child, the number of children in the household, whether at least one parent is not Italian, whether each parents have a university degree, whether both parents were under strict lockdown and whether the respondent is male. Province and day of the week fixed-effects are also included.

\section{Results}

\subsection{Parents' division of housework and childcare}

A closer look at the descriptive analysis of the effects the COVID19 lockdown had on the distribution of household tasks reveals substantial heterogeneous effects. Fig. 1 plots the share of childcare tasks performed by the mother before and during the lockdown in relation to the share of family income she earned before the lockdown. It shows that fathers took up significantly more childcare only for those mothers who earned up to $50 \%$ of the family income. The effect could plausibly be driven by bargaining power. In those households where most of the income is earned by the father, specialization may be at work (Becker, 1981): the husband is more productive in the market work and the wife is more productive in childcare tasks. However, the lockdown forced many workers to stop working, therefore the specialization argument no longer holds. Having more time available, it becomes optimal for fathers to put that time to good use, leading to a reduction in the mothers' share of childcare. In addition it is worth considering that a large share of essential (low wage) workers working in grocery stores, supermarkets, pharmacies, care centers, and so on, are women. They still had to go to work during the lockdown, while their husbands stayed home. This may explain why the statistically significant difference is observed only when the mother earns up to $50 \%$ of family income. ${ }^{12}$

This evidence suggests that the Beckerian household framework can explain the variations observed during the lockdown, where most of the changes in the gender distribution of household tasks would be driven by the changes in the available time of both

\footnotetext{
11 The variable takes values from 0 for "not progressing at all" to 10 "progressing at the same pace as when she/he was attending classes at school."

12 Similar arguments would hold for housework tasks.
} 


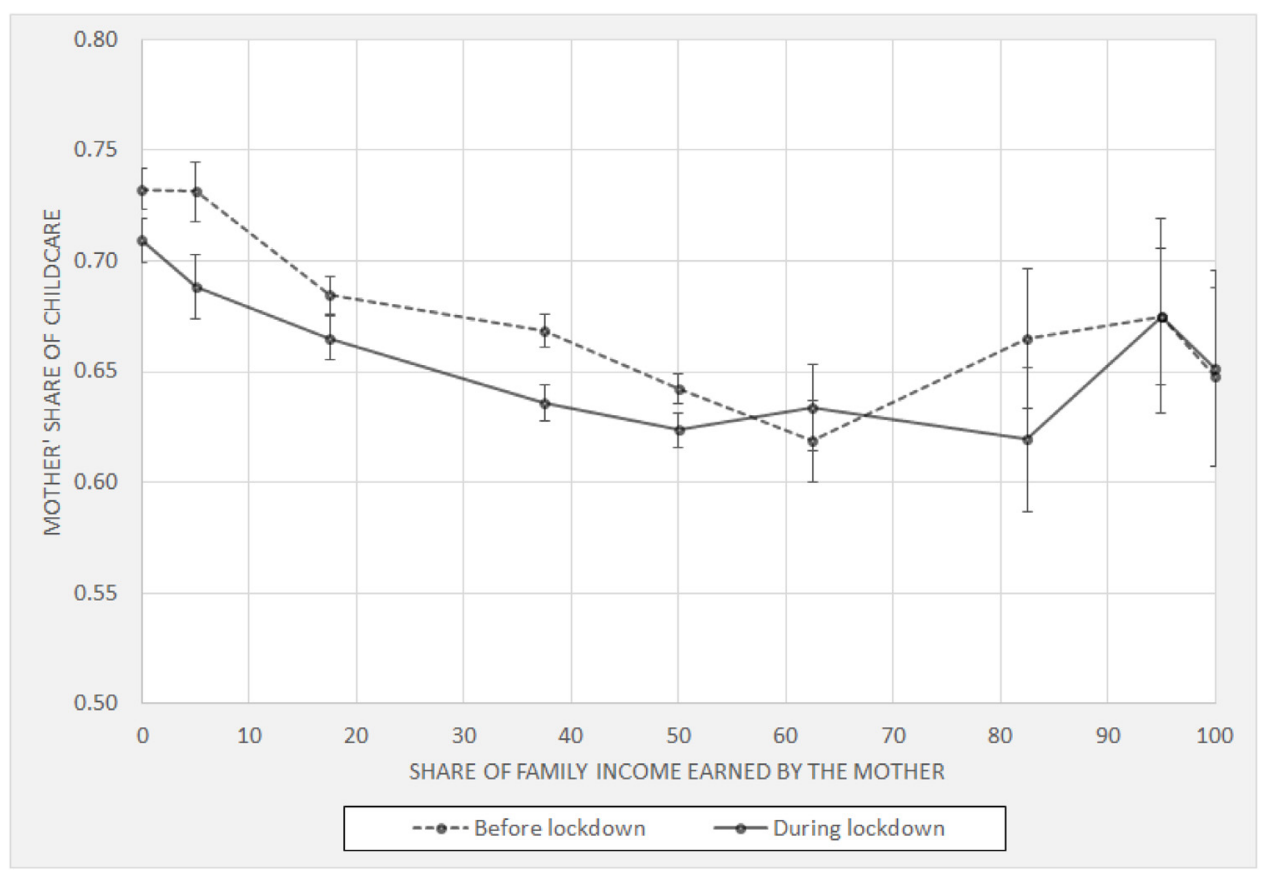

Fig. 1. Variation in the mothers' share of childcare by share of income earned.

partners, as implied by their contingent work situation (Becker, 1981).

This hypothesis is tested by a regression analysis, whose results are reported in Table $1 .{ }^{13}$ The first row reports the overall unconditional variation of the selected outcome during the COVID-19 lockdown and tests whether this is significantly different from zero. The results confirm that the lockdown had a balancing effect on the parents' division of household tasks, reducing the mothers' share of housework by 4.3 percentage points and the mothers' share of childcare tasks by 2.1 percentage points. Although the reduction in childcare tasks is relatively modest, the lockdown increased the probability that the father became the main caregiver by almost 6.6 percentage points.

The regression coefficients reported in Table 1 confirm that which parent stopped working and the reduction of the workload during the lockdown were important factors for determining the parents' division of household tasks. For all three outcomes, when only the father stops working, he takes on more household tasks, while when only the mother stops working, the opposite happens. The mother's coefficient is always smaller than that of the father, which clearly highlights a heterogeneity that explains the small overall variation in the intrahousehold division of housework and childcare during the lockdown. For instance, when the father stops working, the share of housework performed by the mother decreases by 5.3 percentage points. Regarding childcare tasks, the heterogeneous effects of the lockdown is even larger: when only the father stops working, the mother's share of childcare drops by 4.2 percentage points but in addition there is an important effect of the reduction in fathers' working hours. It follows that the probability that the father becomes the main child caregiver during the lockdown increases by 14.5 percentage points when he stops working. A less prominent effect is observed when mothers switch to smart working. The coefficient is only significant at $10 \%$

${ }^{13}$ Full estimation tables are reported in the Appendix, Table A4. and only for childcare tasks, indicating that when the mother switches to smart working she takes on more childcare tasks and the probability that the father becomes the main caregiver is lower. ${ }^{14}$

When accounting for the chosen set of additional control variables and considering the differential impacts by province and day of the week, the lockdown coefficient loses its significance. Full estimation results are reported in Table A4, together with the results of the robustness analysis described in Section 4.3. The table provides some further insights into the analysis: (i) the stop working variable coefficients are very similar when including a large set of covariates, pointing toward the robustness of the results; (ii) the stop working variables alone are not sufficient to make the lockdown coefficient lose significance; (iii) very few of the selected covariates are significant, and the only one significant in all regressions is the share of family income earned by the mother, confirming that families in which there was more gender inequality from the start experienced a stronger equalizing effect during the lockdown; (iv) for childcare, parents education and nationality are the only other relevant variables in explaining the variation in the division of childcare tasks; the effect is substantially larger when both parents have a university degree, while the opposite happens when both parents have a foreign nationality; (v) the duration of the lockdown, measured by the date of interview, tend to have a negative effect on parents' evaluation of both the emotional status and the personal relationship with the child. The hours of TV tend to increase with the date of interview, while the hours of reading tend to decrease. No effect is observed for the evaluation of children's learning progress.

\footnotetext{
14 There may be a concern that work status is nearly collinear with the lockdown. However, the correlation index is only 0.28 for men and 0.25 for women, so correlation is low, and excluding all work status variables from the regressions presented in Table 1 do not change in a meaningful way the lockdown coefficients.
} 
Table 1

The division of housework and childcare during the lockdown.

\begin{tabular}{|c|c|c|c|}
\hline & $\begin{array}{l}\text { (1) } \\
\text { Mothers' share of housework }\end{array}$ & $\begin{array}{l}\text { (2) } \\
\text { Mothers' share of childcare }\end{array}$ & $\begin{array}{l}(3) \\
\text { Father main caregiver }\end{array}$ \\
\hline \multicolumn{4}{|l|}{ Unconditional variation statistics } \\
\hline $\begin{array}{l}\text { Baseline values of the dependent variables before } \\
\text { the lockdown (s.d. in parenthesis) }\end{array}$ & $\begin{array}{l}0.7534 \\
(0.1875)\end{array}$ & $\begin{array}{l}0.6889 \\
(0.1828)\end{array}$ & $\begin{array}{l}0.2819 \\
(0.4500)\end{array}$ \\
\hline Variation of the dependent variables during the lockdown & $\begin{array}{l}-0.0433^{* * *} \\
(0.0033)\end{array}$ & $\begin{array}{l}-0.0212^{* * *} \\
(0.0061)\end{array}$ & $\begin{array}{l}0.0660^{* * *} \\
(0.0131)\end{array}$ \\
\hline \multicolumn{4}{|l|}{ Coefficients of interest (FE regressions) } \\
\hline Lockdown & $\begin{array}{l}0.230 \\
(0.270)\end{array}$ & $\begin{array}{l}-0.0888 \\
(0.440)\end{array}$ & $\begin{array}{l}0.725 \\
(1.093)\end{array}$ \\
\hline Father stopped working & $\begin{array}{l}-0.0523^{* * *} \\
(0.0125)\end{array}$ & $\begin{array}{l}-0.0408^{* * *} \\
(0.0142)\end{array}$ & $\begin{array}{l}0.169^{* * *} \\
(0.0369)\end{array}$ \\
\hline Mother stopped working & $\begin{array}{l}0.0237^{* *} \\
(0.0103)\end{array}$ & $\begin{array}{l}0.0312^{* *} \\
(0.0120)\end{array}$ & $\begin{array}{l}-0.108^{* * *} \\
(0.0355)\end{array}$ \\
\hline Both parents stopped working & $\begin{array}{l}-0.0207 \\
(0.0170)\end{array}$ & $\begin{array}{l}-0.0597^{* *} \\
(0.0228)\end{array}$ & $\begin{array}{l}0.0228 \\
(0.0580)\end{array}$ \\
\hline Mother switched to smartworking & $\begin{array}{l}0.00782 \\
(0.00981)\end{array}$ & $\begin{array}{l}0.0179^{*} \\
(0.0106)\end{array}$ & $\begin{array}{l}-0.0566^{*} \\
(0.0324)\end{array}$ \\
\hline Mother's hours of work (inc. Smartworking) & $\begin{array}{l}-0.00328 \\
(0.00198)\end{array}$ & $\begin{array}{l}-0.00937^{* * *} \\
(0.00275)\end{array}$ & $\begin{array}{l}0.00745 \\
(0.00597)\end{array}$ \\
\hline Father's hours of work (inc. Smartworking) & $\begin{array}{l}0.00403^{* * *} \\
(0.00141)\end{array}$ & $\begin{array}{l}0.00737^{* * * *} \\
(0.00194)\end{array}$ & $\begin{array}{l}-0.0112^{* *} \\
(0.00555)\end{array}$ \\
\hline Observations & 1930 & 1910 & 1910 \\
\hline$R$-squared & 0.139 & 0.155 & 0.111 \\
\hline
\end{tabular}

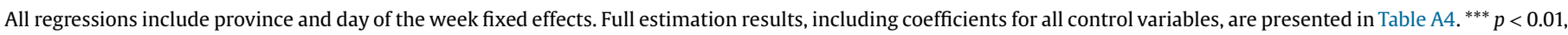
${ }^{* *} p<0.05,{ }^{*} p<0.1$; Clustered standard errors in parentheses (province level), unless otherwise specified.

In summary, the regression results confirm that the changes in the gender division of household tasks induced by the COVID-19 lockdown passed through changes in the work situation and the consequent increase in the time available for housework and childcare (as found also by Sevilla and Smith, 2020, for the UK). In addition, specifically regarding childcare tasks, parents' education also played a key role (as shown in Del Boca et al., 2020), possibly because families in which both parents have a university degree may be more conscious of the potentially beneficial effects of the additional time spent with children by fathers.

\subsection{Children's emotional and educational wellbeing}

If the spring 2020 COVID-19 lockdown had a tremendous impact on adults' lives, it may have had an even stronger one on the lives of children. In Italy, schools were closed at the very beginning of the pandemic and did not reopen until September $14,{ }^{15}$ leaving children with limited interaction with teachers and schoolmates for as much as 6 months.

Fig. 2, for instance, shows how the time breakdown of the typical day of children changed during the lockdown. There is a clear reduction in "productive" activities from a human capital perspective, such as school, homework, and extracurricular activities. Reading time is an exception, although the overall increase is rather limited. External childcare activities see a sharp decrease, for obvious reasons, while non-productive time, including TV, passive screen time, social networks and others, see a dramatic increase Andrew et al. (2020b, see also][for similar results

\footnotetext{
${ }^{15}$ As the educational system comes under regional control, despite the government's guidelines to open on September 14, some regions decided to reopen schools on different dates. For instance, Puglia and Campania re-opened on September 24 because of local elections, other southern regions opened around September 24, while the only anticipation was for the autonomous province of Bolzano, which started on September 7. Individual schools could decide to postpone reopening depending on the number of positive cases within the academic and administrative staff.
}

in the UK). Overall, although productive activities occupied slightly more than $60 \%$ of the typical day before the pandemic upsurge, during Phase I of the lockdown, they sum up to less than $40 \%$ of the considered activities. This is particularly worrying, as the fourmonth reduced school activity period was directly followed by the usual three-month summer vacation period.

The negative effect of school closures is likely to be heterogeneous not only by family socioeconomic status and level of education (Mancini et al., 2017; Mencarini et al., 2019), but also by school level. In fact, according to our data, while approximately $95 \%$ of children attending secondary school had access to distance education classes and material, only approximately $60 \%$ of primary school children had some live online classes, and about $30 \%$ of them only received some learning material accompanied by homework to be delivered through an electronic registry. The situation for pre-school children was even worse, who were practically abandoned by the school system: only $18 \%$ of them had sporadic live online classes, and 37\% received material from their teachers. An astonishing $45 \%$ of these children were never involved in any school activity at the date of interview. Knowing the importance of early childhood education (see Cunha et al., 2010, and the following stream of research on the topic), these children deserve particular attention from policymakers.

The left panel of Fig. 3 provides evidence of such a heterogeneous effect by looking at the evolution of children's TV/screen/ social network and reading time by age class. The starting point of TV time, i.e., before the lockdown, shows how kids of age 3-10 already spent one and a half hours per day watching TV, a figure that rises to $2 \mathrm{~h}$ for older kids. During the lockdown, all children watched much more TV, approximately twice as much. Reading time, as the only educational activity that could to some extent compensate for the decrease in school time and extracurricular activities, also increased but to a much smaller extent (less than half an hour for younger kids and about 10 min for older ones).

Parents were clearly worried about the educational progress of their children during the lockdown, as on a scale from 0 to 10 , the average evaluation was approximately 4.8 , but there was 


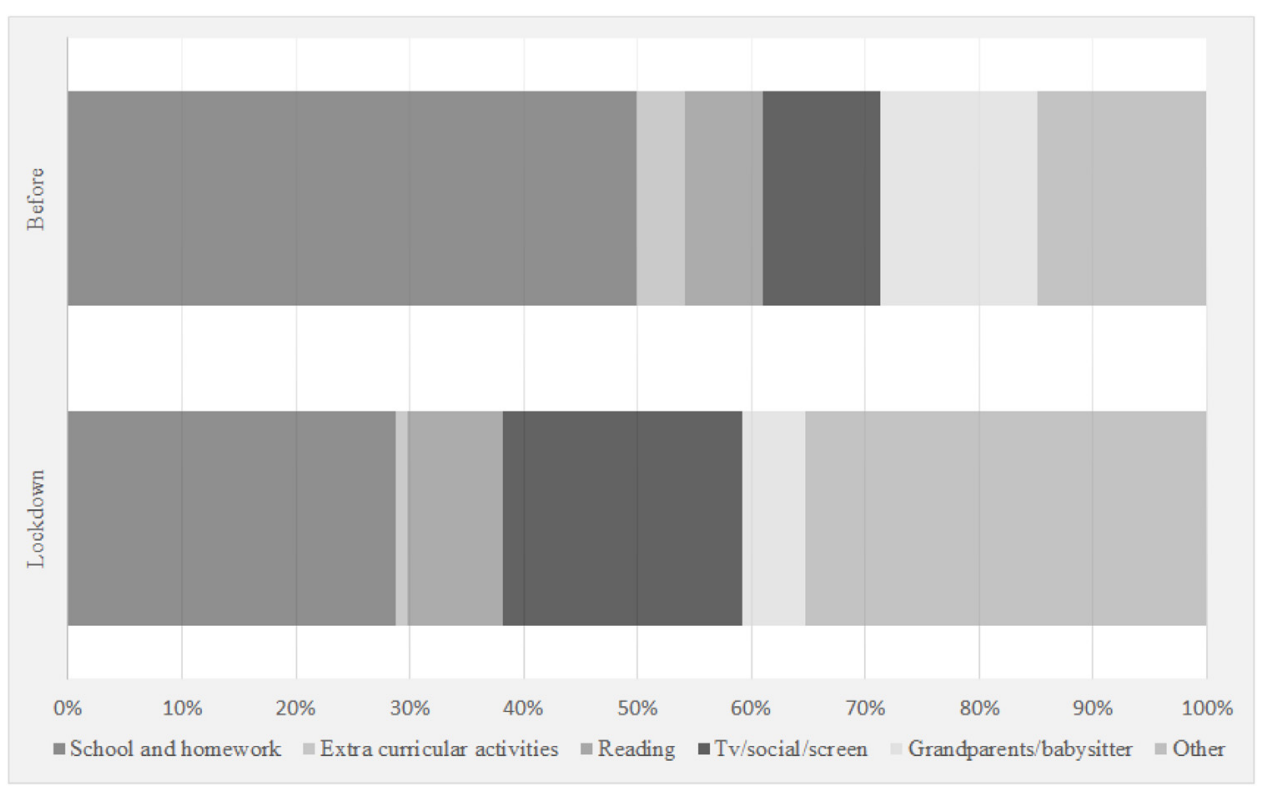

Fig. 2. Typical daily use of time of children, before and during the lockdown.
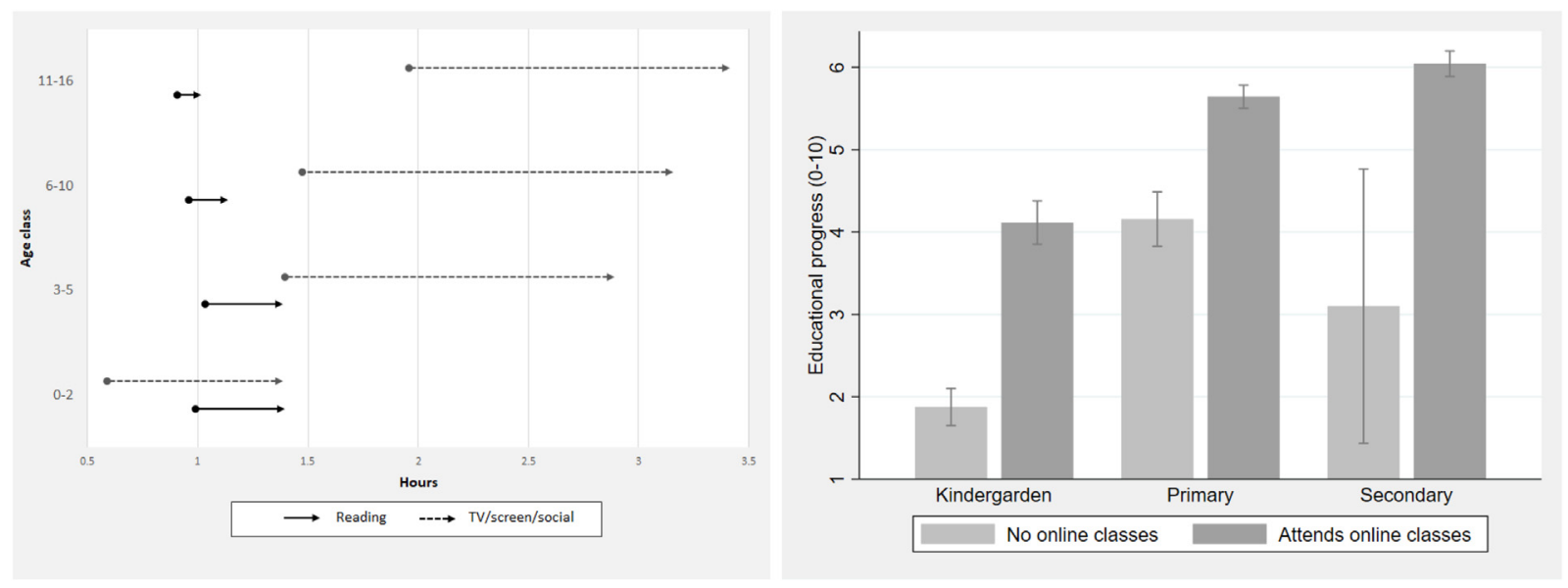

Fig. 3. The evolution of children's TV and reading time by age class, and the parents' evaluation of their children's educational progress.

substantial heterogeneity by school level and, most importantly, by whether the school attended by the child implemented live online classes. The right panel of Fig. 3 highlights how parents of preschool children were particularly worried about their educational progress, with a 2-point difference in the evaluation when the child had some online classes. For primary school children, the evaluation was clearly better, although it approached a score of 6 only for children who attended online classes. A similar result was observed for secondary school children, but in this case, for the few children who did not have online classes, the evaluation decreased by 3 full points.

In addition to the educational outcomes, the COVID-19 lockdown is likely to have produced effects on children's emotional wellbeing (Moroni et al., 2020). Our survey asked two questions in this respect: the first concerns the emotional status of the child, and the second is about the quality of the parent-child relationship. Fig. 4 shows that children of all ages and gender experienced a negative variation of emotional wellbeing during the lockdown, with a slightly stronger impact for boys and a slightly lighter one for secondary school boys and girls. On the other hand, the lockdown moderately improved children's personal relationship with their parents, especially for girls. This effect, although small in magnitude, is notable as it was measured right in the middle of the most difficult phase of the COVID-19 lockdown, with parents struggling to balance smart-working options, housework tasks, children's homework and distance learning education, and possibly economic difficulties.

The variations of the children outcomes under investigation is presented in Table 2 . These include whether the father became the main child caregiver during the lockdown, the couple-total amount of hours devoted to helping children with their homework, and the mother's share of housework.

Looking at the overall variations, the results confirm that the lockdown had a significant effect on children's lives: the emotional status reduces by almost 0.6 points on a scale of -2 to 2 , while personal relationships improved by 0.2 points on the same scale. 
Table 2

Variation of children outcomes during the lockdown.

\begin{tabular}{|c|c|c|c|c|c|}
\hline Variables of interest & $\begin{array}{l}\text { (1) } \\
\text { Emotional status }\end{array}$ & $\begin{array}{l}\text { (2) } \\
\text { Personal relationship }\end{array}$ & $\begin{array}{l}(3) \\
\text { Hours of TV }\end{array}$ & $\begin{array}{l}\text { (4) } \\
\text { Reading hours }\end{array}$ & $\begin{array}{l}\text { (5) } \\
\text { Educational progress }\end{array}$ \\
\hline All children & $\begin{array}{l}-0.588^{* * *} \\
(0.0189)\end{array}$ & $\begin{array}{l}0.194^{* * *} \\
(0.0204)\end{array}$ & $\begin{array}{l}1.516^{* * *} \\
(0.0300)\end{array}$ & $\begin{array}{l}0.240^{* * *} \\
(0.0179)\end{array}$ & $\begin{array}{l}-5.225^{* * *} \\
(0.0590)\end{array}$ \\
\hline \multicolumn{6}{|l|}{ School level } \\
\hline Kindergarten & $\begin{array}{l}-0.598^{* * *} \\
(0.0278)\end{array}$ & $\begin{array}{l}0.264^{* * *} \\
(0.0308)\end{array}$ & $\begin{array}{l}1.421^{* * *} \\
(0.0402)\end{array}$ & $\begin{array}{l}0.365^{* * *} \\
(0.0281)\end{array}$ & $\begin{array}{l}-7.166^{* * *} \\
(0.102)\end{array}$ \\
\hline Primary & $\begin{array}{l}-0.696^{* * *} \\
(0.0286)\end{array}$ & $\begin{array}{l}0.110^{* * *} \\
(0.0311)\end{array}$ & $\begin{array}{l}1.727^{* * *} \\
(0.0450)\end{array}$ & $\begin{array}{l}0.205^{* * *} \\
(0.0247)\end{array}$ & $\begin{array}{l}-4.637^{* * *} \\
(0.0754)\end{array}$ \\
\hline Secondary & $\begin{array}{l}-0.522^{* * *} \\
(0.0387)\end{array}$ & $\begin{array}{l}0.230^{* * *} \\
(0.0399)\end{array}$ & $\begin{array}{l}1.550^{* * *} \\
(0.0723)\end{array}$ & $\begin{array}{l}0.0678^{*} \\
(0.0394)\end{array}$ & $\begin{array}{l}-3.999^{* * *} \\
(0.0895)\end{array}$ \\
\hline
\end{tabular}

*** $p<0.01,{ }^{* *} p<0.05,{ }^{*} p<0.1$ (the null hypothesis is that the variation is equal to zero.)

Table 3

Shift in childcare responsibilities and children's outcomes (FE regressions).

\begin{tabular}{|c|c|c|c|c|c|}
\hline Variables of interest & $\begin{array}{l}\text { (1) } \\
\text { Emotional status }\end{array}$ & $\begin{array}{l}\text { (2) } \\
\text { Personal relationship }\end{array}$ & $\begin{array}{l}(3) \\
\text { Hours of TV }\end{array}$ & $\begin{array}{l}\text { (4) } \\
\text { Reading hours }\end{array}$ & $\begin{array}{l}\text { (5) } \\
\text { Educational progress }\end{array}$ \\
\hline Lockdown & $\begin{array}{l}-0.850^{* * *} \\
(0.157)\end{array}$ & $\begin{array}{l}0.149 \\
(0.182)\end{array}$ & $\begin{array}{l}1.907^{* * * *} \\
(0.258)\end{array}$ & $\begin{array}{l}0.244 \\
(0.152)\end{array}$ & $\begin{array}{l}-8.786^{* * *} \\
(0.453)\end{array}$ \\
\hline Father main caregiver & $\begin{array}{l}0.154^{* * *} \\
(0.0469)\end{array}$ & $\begin{array}{l}0.124^{* *} \\
(0.0534)\end{array}$ & $\begin{array}{l}-0.147^{*} \\
(0.0753)\end{array}$ & $\begin{array}{l}-0.0166 \\
(0.0464)\end{array}$ & $\begin{array}{l}0.195 \\
(0.127)\end{array}$ \\
\hline Total parental homework hours & $\begin{array}{l}-0.0177^{* *} \\
(0.00780)\end{array}$ & $\begin{array}{l}0.00950 \\
(0.00809)\end{array}$ & $\begin{array}{l}0.0216^{*} \\
(0.0126)\end{array}$ & $\begin{array}{l}0.00970 \\
(0.00795)\end{array}$ & $\begin{array}{l}-0.0566^{* * *} \\
(0.0186)\end{array}$ \\
\hline Mother' share of housework & $\begin{array}{l}-0.00898 \\
(0.161)\end{array}$ & $\begin{array}{l}-0.141 \\
(0.183)\end{array}$ & $\begin{array}{l}0.633^{* *} \\
(0.297)\end{array}$ & $\begin{array}{l}-0.00953 \\
(0.203)\end{array}$ & $\begin{array}{l}0.301 \\
(0.440)\end{array}$ \\
\hline Observations & 2640 & 2648 & 2470 & 2441 & 2578 \\
\hline$R$-squared & 0.134 & 0.089 & 0.094 & 0.083 & 0.316 \\
\hline
\end{tabular}

Full estimates are presented in Tables A5-A9. ${ }^{* * *} p<0.01,{ }^{* *} p<0.05,{ }^{*} p<0.1$; Clustered standard errors in parentheses (household level).
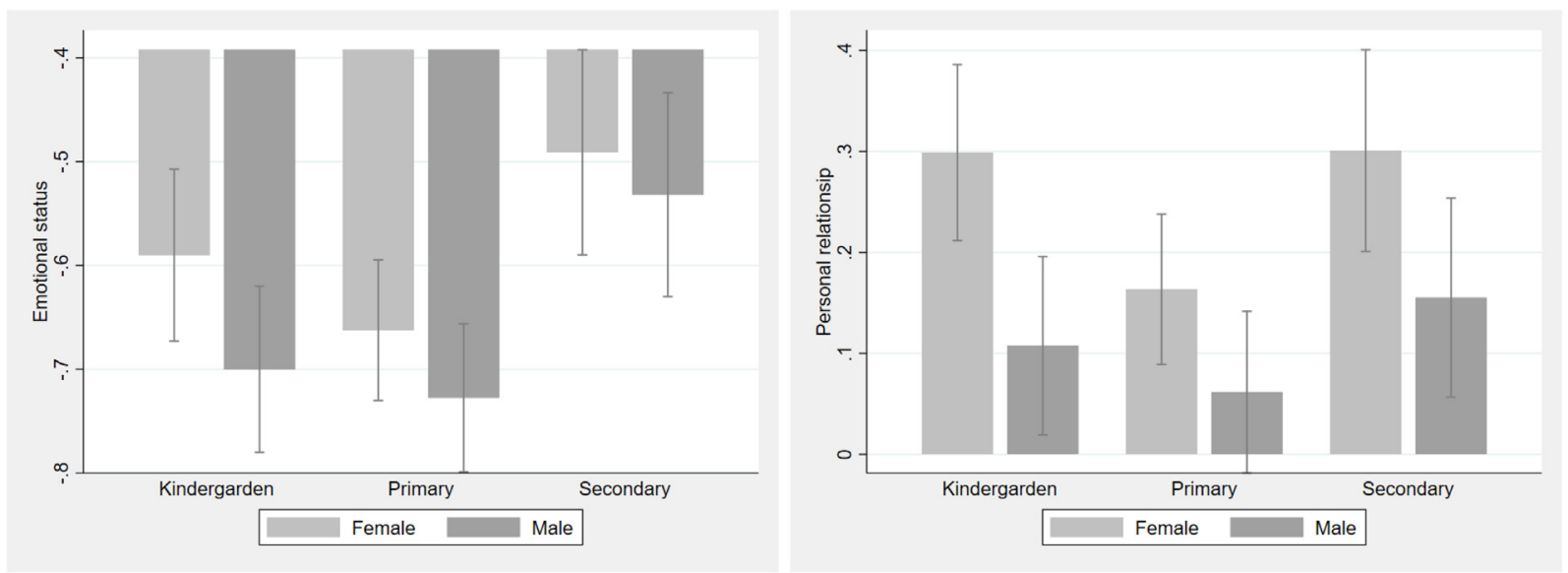

Fig. 4. Variation in the emotional wellbeing and personal relationship by gender and school level.

Hours of TV/screen/social network increase on average by one and a half hours, while reading hours increased only by less than $15 \mathrm{~min}$. The reduction in the educational progress was valued at 5.2 points in a $0-10$ scale. When disentangling what happened to children enrolled in different school levels, a few notable results emerge. First, younger children suffered a little more in terms of emotional wellbeing, but considerably more in terms of educational outcomes. On the other hand, young children were the group that increased their reading time the most during the lockdown.

The econometric analysis of the same outcomes is presented in Table 3, reporting coefficients for the main variables of interest (full estimation results are reported in Tables A5-A9, column (2)).
The most notable result is that when the father was the main caregiver, the negative effect of the lockdown on children's emotional status was significantly smaller, while the personal relationship improved more. These results seem to stem directly from the additional time fathers can spend with their children, rather than from the increase in childcare time. Also hours of TV increased slightly less when the father was the main caregiver. The positive moderating effect of the father's care on children's emotional status is consistent with the findings in Harris et al. (1998), supporting the idea that fathers' involvement had a positive effect on children's emotional skills both when taking care of young children and when helping older kids with 
homeschooling activities. On the other hand, the father's involvement had no effects on reading hours and on the educational progress.

The amount of time parents spend helping their children with homework or educational activities had, instead, a negative effect of children's emotional status and educational progress, as suggested also in the previous literature (Hsin and Felfe, 2014). This, rather than as a causal effect, should probably be interpreted as a measurement effect: if parents spend more time with their children they could possibly be more aware of the negative effect that the lockdown had on them. A higher involvement of parents in their children educational process is also associated with an increase in TV time. Finally, in line with expectations, parental division of housework was not important in explaining children's emotional wellbeing and educational progress, but when mothers had to do a larger share of housework tasks, children spent more time watching TV.

It is worth noting that even controlling for a large set of covariates, the lockdown still had a direct impact on children's outcomes: even when the lockdown coefficient in Table 3 is not significant, its magnitude - which represent the residual impact of the lockdown after controlling for the set of covariates - is always similar or larger than the overall variation of the dependent variables with the lockdown. This means that several factors were able to attenuate some of the negative effects of the lockdown, thus the descriptive analysis could possibly underestimate such negative effects.

Tables A5-A9 show the full set of coefficients for each outcome. ${ }^{16}$ Among the notable results, Table A5 shows how children's emotional status worsened less when doing more live on-line classes and extra-curricular activities, when the child had siblings (the more there are, the better), when at least one parent is not Italian, when parents are more educated, and, perhaps surprisingly, when both parents were under strict lockdown. Table A6 highlights similar patterns for the contribution of the covariates to the parent-child relationship, with the exception of observing significant negative effect of being boys an no effects of the number of siblings.

As to the change in hours of TV (Table A7), the increase was attenuated only by the hours of extracurricular activities and by having both parents with a university degree. In this case, the effect of the lockdown seems to stem directly from the increased availability of time and stronger preferences for TV versus reading or other activities that could be done at home. In terms of reading hours (Table A8), the only significant factor in the FE regression is having highly educated parents and having both parents under strict lockdown, both of which have a positive coefficient. Having al least one parent that is not Italian also moderately increases reading time, but the coefficient is significant only at $10 \%$ and not in all specifications.

Finally, as shown in Table A9, results for the evaluation of educational progress indicate that most of the negative effect is explained by the number of distance learning hours and by the hours of extracurricular activities. ${ }^{17}$ The educational progress evaluation has been worse for boys and younger children, and, again, having both parents under strict lockdown improved their evaluation. The latter result seems unrelated with the increased availability of time to be spent with children, as the coefficient of parental time spent in helping children with homework is negative and significant.

\footnotetext{
${ }^{16}$ These tables also present the results of the robustness analyses presented in Section 4.3 .

17 See Champeaux et al. (2021) for a more detailed analysis of the impact of distance learning activities on children's educational outcomes
}

\subsection{Robustness analysis}

The previous pages presented the results of the linear fixedeffect regressions introduced in Section 3.2 to study how a greater involvement of fathers in childcare tasks during the spring 2020 lockdown may have influenced children's emotional wellbeing and educational progress. Although Section 4.1 highlighted how this shift in parental responsibilities was largely due to the exogenous labor supply shock induced by the lockdown, in this section we propose a battery of robustness test on the possible concern that the results may be driven by particular characteristics of the data and/or the empirical strategy.

First, we compare the coefficient of interest in the main regressions with those from the same regression but without the large set of covariates. Stability of the coefficients is an indication that significant relationships do not emerge from spurious correlation and that it is unlikely to be severely affected by unobserved heterogeneity issues. Tables A5, A6 and A7 show that when the coefficient of the variables of interest are significant in the main regressions (column (2) in the Tables), they are very stable with respect to the exclusion of all covariates and fixed effects.

A second robustness test provides evidence for the quality of the data. As explained in Section 3.1, the survey was developed urgently right after the onset of the first lockdown, and we were able to start the dissemination in less than one month. For this reason, the survey was conducted without a sampling strategy. This implies that the data cannot claim to be representative of the Italian population in any dimension. While some characteristics of the sample were very close to national statistics, as exposed in Section 3.1 and Table A1, we have detected significant deviations that may affect our results. In particular, we refer to a much higher proportion of individuals with a university degree, a lower proportion of foreign born individuals, a higher participation in the labor market and an under-representation of southern regions. To be sure that these differences do not drive our results, we have computed post-stratification weights calibrated on most of the characteristics reported in Table A1 using a iterative proportional fitting, or raking, procedure. ${ }^{18}$ Then the main regressions have been replicated using the calibrated weights, and the results are presented in columns (3) of Table A5-A9. The use of calibrated weights did not affect significantly the coefficient of interest except for the coefficients for TV hours, which become all non-significant, and for the coefficient of father main caregiver on the educational progress, which becomes positive and significant at $5 \%$.

Another possible concern regarding the data is that most respondents to the survey are female. This implies that the results mostly reflect mothers opinion on children's outcomes, but as fathers opinion may be radically different, besides controlling for respondent's gender using a dummy, we also perform the same regressions on the subsample of female respondents only (see Tables A5-A9, columns (3)), finding no significant differences in the parameters of interest.

The fourth robustness check is about the choice of constructing a dummy variable for the father becoming the main caregiver rather using directly the continuous variable father share of childcare. While our choice was motivated by ease of

\footnotetext{
${ }^{18}$ In particular the raking procedure was targeted to the actual regional distribution of the population, the number of children, the proportion of women and men of comparable age with university degree, their working condition, and their nationality.
} 
interpretation, column (4) of Tables A5-A9 report the results of the main regressions using the continuous variable rather than the dummy. The sign and significance of the coefficients are confirmed for all outcomes except for parent-child relationship, which becomes non-significant. The last robustness analysis is related to the econometric model to be applied. As educational status and personal relationship are categorical variables whose numerical values have little relevance, it could be appropriate to estimate them using ordered logistic regressions. The same is also applied to TV hours, reading hours and educational evaluation because, although theoretically continuous variables, they are quite concentrated around some integer values as if they were categorical. The results are presented in column (5) of Tables A5-A9 and are all strongly consistent with the main estimates, sometimes with gains in significance of a few control variables.

\section{Conclusions}

Italian families, as well as many other families around the world, were challenged during the COVID-19 pandemic with an almost complete lockdown. Children were heavily affected: schools were immediately closed as well as any form of childcare services or extracurricular activities. In both cases, attempts to provide distance learning solutions were highly heterogeneous, both in quantity and in quality, with likely negative long-run effects on human capital accumulation and educational inequality. In addition, the imposition of staying at home except in cases of absolute necessity strongly limited children's social lives and their possibility to develop soft skills through peer interactions, possibly affecting their emotional wellbeing.

In this study, we analyzed how the intrahousehold division of housework and childcare have changed during the lockdown, and how these, in turn, have influenced children's emotional wellbeing and learning process. To accomplish this, we performed descriptive analyses and fixed-effect regressions using real-time survey data developed for this purpose and collected right in the middle of the stronger Italian COVID-19 lockdown phase, in April 2020. While recent studies have investigated the consequences of the COVID-19 outbreak on the reallocation of market and unpaid work, this is, to the best of our knowledge, the first study to investigate how these changes affected children's wellbeing jointly with the lockdown itself.

The results suggest that changes in the intrahousehold distribution of housework and childcare tasks can be largely explained by the exogenous increase in the available time for those parents that had to stop working during the lockdown. Taking advantage of this exogenous variation, we evaluate the effects of the lockdown on children's emotional wellbeing and learning process and to which degree the shift in childcare roles toward fathers had an influence on children. We find that fathers matter: when they become the main child caregiver, children's emotional wellbeing increases significantly, both in terms of emotional status and relationship with their parents. In addition, they watch a little less TV, an unproductive activity that increased substantially with the lockdown. These results survive a battery of robustness checks on the empirical strategy.

Despite data limitations, our results provide support to implement policies aimed at increasing fathers' involvement in childcare activities, such as increased mandatory paternity leave periods and more flexible work arrangements. All of these potential implementations would have positive effects on children's wellbeing with the additional advantage of contributing to re-balancing women's workload (at home and in the market), and would possibly shift Italian gender norms from the traditional family structure to more egalitarian role models in the longer term.

\section{Authors' contribution}

Lucia Mangiavacchi: Conceptualization, Methodology, Software, Formal analysis, Investigation, Data Curation, Writing Original Draft, Writing - Review \& Editing, Visualization. Luca Piccoli: Conceptualization, Methodology, Software, Formal analysis, Investigation, Data Curation, Writing - Original Draft, Writing Review \& Editing, Visualization. Luca Pieroni: Conceptualization, Methodology, Software, Formal analysis, Investigation, Data Curation, Writing - Original Draft, Writing - Review \& Editing, Visualization.

\section{Appendix A. Additional tables}

Tables A1-A9

Table A1

Comparison of key variables with ISTAT surveys.

\begin{tabular}{|c|c|c|}
\hline Variables & Our sample & ISTAT \\
\hline \multicolumn{3}{|l|}{ Family type $e^{1}$} \\
\hline Couples with 1 child & $44.0 \%$ & $47.9 \%$ \\
\hline Couples with 2 children & $46.8 \%$ & $41.7 \%$ \\
\hline Couples with 3 or more children & $9.1 \%$ & $10.4 \%$ \\
\hline \multicolumn{3}{|l|}{ Geographical distribution ${ }^{2}$} \\
\hline North & $53.6 \%$ & $46.0 \%$ \\
\hline Center & $26.7 \%$ & $19.9 \%$ \\
\hline South & $19.7 \%$ & $34.1 \%$ \\
\hline \multicolumn{3}{|l|}{ University degree $^{3}$} \\
\hline Females & $59.9 \%$ & $29.2 \%$ \\
\hline Males & $38.8 \%$ & $19.5 \%$ \\
\hline \multicolumn{3}{|l|}{ Working $^{3}$} \\
\hline Females & $78.6 \%$ & $62.8 \%$ \\
\hline Males & $96.0 \%$ & $84.9 \%$ \\
\hline \multicolumn{3}{|l|}{ Foreign born ${ }^{4}$} \\
\hline Females & $4.7 \%$ & $8.9 \%$ \\
\hline Males & $4.5 \%$ & $8.7 \%$ \\
\hline \multicolumn{3}{|l|}{ Parents ${ }^{5}$} \\
\hline Mother' share of housework & $73.0 \%$ & $73.3 \%$ \\
\hline Mother' share of childcare & $66.8 \%$ & $62.7 \%$ \\
\hline \multicolumn{3}{|l|}{ Children $3-5^{5}$} \\
\hline Hours of TV & 1.37 & 1.25 \\
\hline Hours of reading & 1.02 & 0.42 \\
\hline \multicolumn{3}{|l|}{ Children $6-10^{5}$} \\
\hline Hours of TV & 1.45 & 1.57 \\
\hline Hours of reading & 0.94 & 0.46 \\
\hline \multicolumn{3}{|l|}{ Children $11-14^{5}$} \\
\hline Hours of TV & 1.96 & 1.72 \\
\hline Hours of reading & 0.90 & 0.55 \\
\hline
\end{tabular}

Notes: (1) Reference population shares are drawn from the Multipurpose Survey on Households: Aspects of Daily Life 2019. (2) Reference values are drawn from Resident Municipal Population on January 1 2019. (3) Reference values are the share of males and females aged 30-49 with a university degree, drawn from the 2019 Labour Force Survey. (4) Source Resident Population at January 1st 2020. (5). Reference values are drawn to the 2013 Italian Time Use Survey, for a sample of biactive couples with children, with the woman in the age range 25-64. For comparative purposes, the same conditions have been applied to our samples, whose reference values reflect what was stated as the pre-lockdown situation. 
Table A2

Descriptive statistics for the sample of couples with children.

\begin{tabular}{|c|c|c|c|c|}
\hline \multirow[t]{2}{*}{ Variable } & \multicolumn{2}{|c|}{ Before Lockdown } & \multicolumn{2}{|c|}{ During lockdown } \\
\hline & Mean & S.d. & Mean & S.d. \\
\hline Mother's share of housework & 0.754 & 0.188 & 0.710 & 0.195 \\
\hline Mother's share of childcare & 0.689 & 0.183 & 0.667 & 0.199 \\
\hline Father main caregiver & 0.281 & 0.450 & 0.348 & 0.476 \\
\hline Total parental homework hours & 3.108 & 2.745 & 6.453 & 4.458 \\
\hline Mother's work status ( $1=$ working, $0=$ other $)$ & 0.786 & 0.410 & 0.507 & 0.500 \\
\hline Father's work status ( $1=$ working, $0=$ other $)$ & 0.960 & 0.197 & 0.704 & 0.457 \\
\hline Mother's daily hours of work (inc. smart working) & 4.181 & 2.662 & 2.810 & 2.942 \\
\hline Father's daily hours of work (inc. smart working) & 6.163 & 2.514 & 4.561 & 3.322 \\
\hline Grandparents' hours of childcare & 2.210 & 2.532 & 0.790 & 2.218 \\
\hline Babysitter's hours of childcare & 0.343 & 1.126 & 0.109 & 0.750 \\
\hline Mother under strict lockdown & - & - & 0.030 & 0.171 \\
\hline Father under strict lockdown & - & - & 0.018 & 0.132 \\
\hline Mother switched to smart working during lockdown & - & - & 0.140 & 0.347 \\
\hline Share of family income earned by the mother & 0.341 & 0.236 & - & - \\
\hline Age of mother & 41.234 & 5.736 & - & - \\
\hline Age of father & 43.854 & 6.360 & - & - \\
\hline Age difference ratio & 0.515 & 0.026 & - & - \\
\hline Respondent is male & 0.069 & 0.253 & - & - \\
\hline 2 or more children in the household & 0.554 & 0.497 & - & - \\
\hline Presence of other adults in the household & 0.118 & 0.322 & - & - \\
\hline Father has a university degree & 0.587 & 0.493 & - & - \\
\hline Mother has a university degree & 0.374 & 0.484 & - & - \\
\hline Both parents have non-Italian nationality & 0.015 & 0.121 & - & - \\
\hline Observations & 2101 & & & \\
\hline
\end{tabular}

Table A3

Descriptive statistics for the sample of children.

\begin{tabular}{|c|c|c|c|c|c|c|}
\hline \multirow[t]{2}{*}{ Variable } & \multicolumn{2}{|c|}{ Before Lockdown } & \multicolumn{2}{|c|}{ During lockdown } & \multicolumn{2}{|c|}{ Variation } \\
\hline & Mean & S.d. & Mean & S.d. & Mean & S.d. \\
\hline Emotional status1 & - & - & - & - & -0.585 & 0.957 \\
\hline Personal relationship1 & - & - & - & - & 0.193 & 1.019 \\
\hline Evaluation of educational progress2 & - & - & - & - & 4.778 & 2.861 \\
\hline TV hours per day & 1.444 & 0.961 & 2.913 & 1.615 & 1.510 & 1.468 \\
\hline Reading hours per day & 0.971 & 0.733 & 1.206 & 0.964 & 0.239 & 0.880 \\
\hline Extracurricular activities hours per week & 0.597 & 0.510 & 0.137 & 0.324 & -0.461 & 0.518 \\
\hline Child is male & 0.507 & 0.500 & - & - & - & - \\
\hline Age of child & 7.082 & 4.121 & - & - & - & - \\
\hline Distance learning hours & 1.199 & 1.418 & - & - & - & - \\
\hline \multicolumn{7}{|l|}{ School level } \\
\hline Kindergarten & 0.375 & 0.484 & - & - & - & - \\
\hline Primary & 0.403 & 0.491 & - & - & - & - \\
\hline Secondary & 0.222 & 0.415 & - & - & - & - \\
\hline Observations & 3619 & & & & & \\
\hline
\end{tabular}

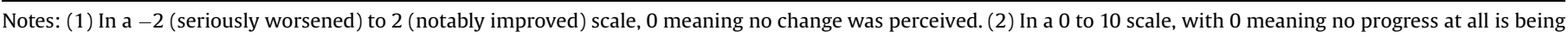
made, 10 the child is progressing as if $s /$ he was attending school. 
Table A4

Full regression estimates for parents' outcomes.

\begin{tabular}{|c|c|c|c|c|c|c|}
\hline \multirow[b]{3}{*}{ Constant } & (1) & $(2)$ & (3) & $(4)$ & (5) & $(6)$ \\
\hline & \multicolumn{2}{|c|}{ Mother's share of housework } & \multicolumn{2}{|c|}{ Mother's share of childcare } & \multicolumn{2}{|c|}{ Father main caregiver } \\
\hline & $\begin{array}{l}-0.0418^{* * *} \\
(0.00525)\end{array}$ & $\begin{array}{l}0.230 \\
(0.270)\end{array}$ & $\begin{array}{l}-0.0213^{* * *} \\
(0.00558)\end{array}$ & $\begin{array}{l}-0.0888 \\
(0.440)\end{array}$ & $\begin{array}{l}0.0661^{* * *} \\
(0.0172)\end{array}$ & $\begin{array}{l}0.725 \\
(1.093)\end{array}$ \\
\hline Father stopped working during the lockdown & $\begin{array}{l}-0.0496^{* * * *} \\
(0.0119)\end{array}$ & $\begin{array}{l}-0.0523^{* * *} \\
(0.0125)\end{array}$ & $\begin{array}{l}-0.0309^{* *} \\
(0.0139)\end{array}$ & $\begin{array}{l}-0.0408^{* * * *} \\
(0.0142)\end{array}$ & $\begin{array}{l}0.140^{* * * *} \\
(0.0339)\end{array}$ & $\begin{array}{l}0.169 * * * \\
(0.0369)\end{array}$ \\
\hline Mother stopped working during the lockdown & $\begin{array}{l}0.0221^{* *} \\
(0.00943)\end{array}$ & $\begin{array}{l}0.0237^{* *} \\
(0.0103)\end{array}$ & $\begin{array}{l}0.0362^{* * *} \\
(0.0105)\end{array}$ & $\begin{array}{l}0.0312^{* *} \\
(0.0120)\end{array}$ & $\begin{array}{l}-0.104^{* * *} \\
(0.0349)\end{array}$ & $\begin{array}{l}-0.108^{* * *} \\
(0.0355)\end{array}$ \\
\hline Both parents stopped working during the lockdown & $\begin{array}{l}-0.0153 \\
(0.0159)\end{array}$ & $\begin{array}{l}-0.0207 \\
(0.0170)\end{array}$ & $\begin{array}{l}-0.0523^{* *} \\
(0.0202)\end{array}$ & $\begin{array}{l}-0.0597^{* *} \\
(0.0228)\end{array}$ & $\begin{array}{l}0.0147 \\
(0.0526)\end{array}$ & $\begin{array}{l}0.0228 \\
(0.0580)\end{array}$ \\
\hline Mother switched to smart working during the lockdown & $\begin{array}{l}0.0169^{*} \\
(0.00935)\end{array}$ & $\begin{array}{l}0.00782 \\
(0.00981)\end{array}$ & $\begin{array}{l}0.0142 \\
(0.0104)\end{array}$ & $\begin{array}{l}0.0179^{*} \\
(0.0106)\end{array}$ & $\begin{array}{l}-0.0595^{*} \\
(0.0318)\end{array}$ & $\begin{array}{l}-0.0566^{*} \\
(0.0324)\end{array}$ \\
\hline Mother's hours of work (inc. Smart working) & $\begin{array}{l}-0.00391^{* *} \\
(0.00184)\end{array}$ & $\begin{array}{c}-0.00328 \\
(0.00198)\end{array}$ & $\begin{array}{l}-0.00880^{* * *} \\
(0.00258)\end{array}$ & $\begin{array}{l}-0.00937^{* * *} \\
(0.00275)\end{array}$ & $\begin{array}{l}0.00803 \\
(0.00560)\end{array}$ & $\begin{array}{l}0.00745 \\
(0.00597)\end{array}$ \\
\hline Father's hours of work (inc. Smart working) & $\begin{array}{l}0.00403^{* * *} \\
(0.00141)\end{array}$ & $\begin{array}{l}0.00391^{* * *} \\
(0.00128)\end{array}$ & $\begin{array}{l}0.00772^{* * *} \\
(0.00209)\end{array}$ & $\begin{array}{l}0.00737^{* * *} \\
(0.00194)\end{array}$ & $\begin{array}{l}-0.0125^{* *} \\
(0.00536)\end{array}$ & $\begin{array}{l}-0.0112^{* *} \\
(0.00555)\end{array}$ \\
\hline Variation in grandparents' hours of childcare & & $\begin{array}{l}0.00164 \\
(0.00110)\end{array}$ & & $\begin{array}{l}0.000955 \\
(0.00124)\end{array}$ & & $\begin{array}{l}-0.00311 \\
(0.00330)\end{array}$ \\
\hline Variation in babysitter's hours of childcare & & $\begin{array}{l}0.000402 \\
(0.00336)\end{array}$ & & $\begin{array}{l}-0.00485 \\
(0.00358)\end{array}$ & & $\begin{array}{l}0.00971 \\
(0.00903)\end{array}$ \\
\hline Share of family income earned by the mother & & $\begin{array}{l}0.0605^{* * *} \\
(0.0120)\end{array}$ & & $\begin{array}{l}0.0433^{* *} \\
(0.0209)\end{array}$ & & $\begin{array}{l}-0.121^{* *} \\
(0.0474)\end{array}$ \\
\hline Age of mother & & $\begin{array}{l}-0.00345 \\
(0.00310)\end{array}$ & & $\begin{array}{l}-0.000383 \\
(0.00459)\end{array}$ & & $\begin{array}{l}-0.00653 \\
(0.0120)\end{array}$ \\
\hline Age of father & & $\begin{array}{l}0.00362 \\
(0.00290)\end{array}$ & & $\begin{array}{l}0.000857 \\
(0.00458)\end{array}$ & & $\begin{array}{l}0.00275 \\
(0.0117)\end{array}$ \\
\hline Age difference ratio & & $\begin{array}{l}-0.531 \\
(0.508)\end{array}$ & & $\begin{array}{l}0.0522 \\
(0.881)\end{array}$ & & $\begin{array}{l}-1.103 \\
(2.169)\end{array}$ \\
\hline Respondent is male & & $\begin{array}{l}-0.0240^{*} \\
(0.0135)\end{array}$ & & $\begin{array}{l}0.00531 \\
(0.0236)\end{array}$ & & $\begin{array}{l}-0.0175 \\
(0.0484)\end{array}$ \\
\hline 2 or more children in the household & & $\begin{array}{l}-0.0185^{* *} \\
(0.00878)\end{array}$ & & $\begin{array}{l}0.00426 \\
(0.00898)\end{array}$ & & $\begin{array}{l}0.0131 \\
(0.0267)\end{array}$ \\
\hline Presence of other adults in the household & & $\begin{array}{l}-0.0138 \\
(0.00854)\end{array}$ & & $\begin{array}{l}-0.0180 \\
(0.0144)\end{array}$ & & $\begin{array}{l}0.0825^{* *} \\
(0.0380)\end{array}$ \\
\hline Only father has a university degree & & $\begin{array}{l}-0.00917 \\
(0.0173)\end{array}$ & & $\begin{array}{l}-0.0229 \\
(0.0150)\end{array}$ & & $\begin{array}{l}0.0438 \\
(0.0469)\end{array}$ \\
\hline Only mother has a university degree & & $\begin{array}{l}0.00297 \\
(0.00799)\end{array}$ & & $\begin{array}{l}-0.0218^{* *} \\
(0.0108)\end{array}$ & & $\begin{array}{l}0.0375 \\
(0.0257)\end{array}$ \\
\hline Both parents have a university degree & & $\begin{array}{l}-0.00514 \\
(0.00948)\end{array}$ & & $\begin{array}{l}-0.0375^{* * *} \\
(0.0107)\end{array}$ & & $\begin{array}{l}0.0815^{* * *} \\
(0.0283)\end{array}$ \\
\hline Both parents have non-Italian nationality & & $\begin{array}{l}-0.0219 \\
(0.0202)\end{array}$ & & $\begin{array}{l}0.0652^{* * *} \\
(0.0247)\end{array}$ & & $\begin{array}{l}-0.156^{* *} \\
(0.0764)\end{array}$ \\
\hline Province FE & - & Yes & - & Yes & - & Yes \\
\hline Day of week FE & - & Yes & - & Yes & - & Yes \\
\hline Observations & 2098 & 1930 & 2067 & 1910 & 2067 & 1910 \\
\hline$R$-squared & 0.059 & 0.139 & 0.084 & 0.155 & 0.047 & 0.111 \\
\hline
\end{tabular}

${ }^{* * *} p<0.01,{ }^{* *} p<0.05,{ }^{*} p<0.1$; Robust standard errors in brackets (clustered at province level). 
Table A5

Full regression estimates for children's emotional status.

\begin{tabular}{|c|c|c|c|c|c|c|}
\hline Emotional status & $\begin{array}{l}\text { (1) } \\
\text { OLS }\end{array}$ & $\begin{array}{l}(2) \\
\text { OLS }\end{array}$ & $\begin{array}{l}(3) \\
\text { Female resp. }\end{array}$ & $\begin{array}{l}\text { (4) } \\
\text { Weight }\end{array}$ & $\begin{array}{l}\text { (5) } \\
\text { Cont. Var. }\end{array}$ & $\begin{array}{l}(6) \\
\text { Ologit }^{1}\end{array}$ \\
\hline Constant & $\begin{array}{l}-0.553^{* * * *} \\
(0.0325)\end{array}$ & $\begin{array}{l}-0.850^{* * * *} \\
(0.157)\end{array}$ & $\begin{array}{l}-0.879^{* * *} \\
(0.170)\end{array}$ & $\begin{array}{l}-0.849^{* * *} \\
(0.237)\end{array}$ & $\begin{array}{l}-0.826^{* * *} \\
(0.159)\end{array}$ & \\
\hline Father main caregiver & $\begin{array}{l}0.158^{* * *} \\
(0.0415)\end{array}$ & $\begin{array}{l}0.154^{* * *} \\
(0.0469)\end{array}$ & $\begin{array}{l}0.160^{* * * *} \\
(0.0492)\end{array}$ & $\begin{array}{l}0.124^{* *} \\
(0.0557)\end{array}$ & & $\begin{array}{l}0.345^{* * *} \\
(0.0966)\end{array}$ \\
\hline Variation in father's share of childcare & & & & & $\begin{array}{l}0.321^{* *} \\
(0.146)\end{array}$ & \\
\hline Total parental homework hours & $\begin{array}{l}-0.0241^{* * *} \\
(0.00659)\end{array}$ & $\begin{array}{l}-0.0177^{* *} \\
(0.00780)\end{array}$ & $\begin{array}{l}-0.0168^{* *} \\
(0.00814)\end{array}$ & $\begin{array}{l}-0.0266^{* * *} \\
(0.00925)\end{array}$ & $\begin{array}{l}-0.0163^{* *} \\
(0.00775)\end{array}$ & $\begin{array}{l}-0.0425^{* * *} \\
(0.0163)\end{array}$ \\
\hline Mother's share of housework & $\begin{array}{l}-0.00848 \\
(0.149)\end{array}$ & $\begin{array}{l}-0.00898 \\
(0.161)\end{array}$ & $\begin{array}{l}-0.0186 \\
(0.173)\end{array}$ & $\begin{array}{l}-0.0116 \\
(0.211)\end{array}$ & $\begin{array}{l}0.0561 \\
(0.170)\end{array}$ & $\begin{array}{l}-0.0537 \\
(0.335)\end{array}$ \\
\hline Child is male & & $\begin{array}{l}-0.0483 \\
(0.0356)\end{array}$ & $\begin{array}{l}-0.0493 \\
(0.0374)\end{array}$ & $\begin{array}{l}0.0190 \\
(0.0520)\end{array}$ & $\begin{array}{l}-0.0470 \\
(0.0357)\end{array}$ & $\begin{array}{l}-0.116 \\
(0.0744)\end{array}$ \\
\hline Age of child & & $\begin{array}{l}-0.0130 \\
(0.0109)\end{array}$ & $\begin{array}{l}-0.0121 \\
(0.0117)\end{array}$ & $\begin{array}{l}-0.00546 \\
(0.0144)\end{array}$ & $\begin{array}{l}-0.0123 \\
(0.0109)\end{array}$ & $\begin{array}{l}-0.0356 \\
(0.0230)\end{array}$ \\
\hline Distance learning hours \# kindergarten & & $\begin{array}{l}0.0718 \\
(0.0640)\end{array}$ & $\begin{array}{l}0.0630 \\
(0.0667)\end{array}$ & $\begin{array}{l}0.101 \\
(0.0822)\end{array}$ & $\begin{array}{l}0.0746 \\
(0.0640)\end{array}$ & $\begin{array}{l}0.125 \\
(0.132)\end{array}$ \\
\hline Distance learning hours \# Primary school & & $\begin{array}{l}0.176^{* * *} \\
(0.0517)\end{array}$ & $\begin{array}{l}0.167^{* * *} \\
(0.0541)\end{array}$ & $\begin{array}{l}0.136^{* *} \\
(0.0683)\end{array}$ & $\begin{array}{l}0.166^{* * *} \\
(0.0519)\end{array}$ & $\begin{array}{l}0.375^{* * * *} \\
(0.112)\end{array}$ \\
\hline Distance learning hours \# Secondary school & & $\begin{array}{l}0.365^{* * *} \\
(0.0886)\end{array}$ & $\begin{array}{l}0.378^{* * *} \\
(0.0950)\end{array}$ & $\begin{array}{l}0.269^{* *} \\
(0.122)\end{array}$ & $\begin{array}{l}0.355^{* * *} \\
(0.0885)\end{array}$ & $\begin{array}{l}0.813^{* * * *} \\
(0.191)\end{array}$ \\
\hline Hours of extra curricular activities & & $\begin{array}{l}0.304^{* * *} \\
(0.0463)\end{array}$ & $\begin{array}{l}0.317^{* * *} \\
(0.0495)\end{array}$ & $\begin{array}{l}0.269^{* * *} \\
(0.0655)\end{array}$ & $\begin{array}{l}0.303^{* * *} \\
(0.0466)\end{array}$ & $\begin{array}{l}0.584^{* * *} \\
(0.0914)\end{array}$ \\
\hline 2 children in the household & & $\begin{array}{l}0.0837^{*} \\
(0.0476)\end{array}$ & $\begin{array}{l}0.101^{* *} \\
(0.0501)\end{array}$ & $\begin{array}{l}0.0545 \\
(0.0596)\end{array}$ & $\begin{array}{l}0.0823^{*} \\
(0.0477)\end{array}$ & $\begin{array}{l}0.216^{* *} \\
(0.0990)\end{array}$ \\
\hline 3 children in the household & & $\begin{array}{l}0.217^{* * *} \\
(0.0707)\end{array}$ & $\begin{array}{l}0.236^{* * * *} \\
(0.0741)\end{array}$ & $\begin{array}{l}0.165^{*} \\
(0.0930)\end{array}$ & $\begin{array}{l}0.200^{* * *} \\
(0.0704)\end{array}$ & $\begin{array}{l}0.582^{* * * *} \\
(0.151)\end{array}$ \\
\hline 4 children in the household & & $\begin{array}{l}0.555^{* *} \\
(0.227)\end{array}$ & $\begin{array}{l}0.574^{* *} \\
(0.233)\end{array}$ & $\begin{array}{l}0.723^{* * *} \\
(0.188)\end{array}$ & $\begin{array}{l}0.572^{* *} \\
(0.238)\end{array}$ & $\begin{array}{l}1.354^{* * *} \\
(0.491)\end{array}$ \\
\hline More than 4 children in the household & & $\begin{array}{l}1.022^{* * *} \\
(0.393)\end{array}$ & $\begin{array}{l}1.012^{* *} \\
(0.394)\end{array}$ & $\begin{array}{l}0.963^{* * *} \\
(0.293)\end{array}$ & $\begin{array}{l}0.957^{* *} \\
(0.397)\end{array}$ & $\begin{array}{l}2.184^{* * * *} \\
(0.548)\end{array}$ \\
\hline At least one parent is not Italian & & $\begin{array}{l}0.174 * * * \\
(0.0643)\end{array}$ & $\begin{array}{l}0.175^{* * * *} \\
(0.0678)\end{array}$ & $\begin{array}{l}0.230^{* * *} \\
(0.0752)\end{array}$ & $\begin{array}{l}0.175^{* * *} \\
(0.0644)\end{array}$ & $\begin{array}{l}0.411^{* * *} \\
(0.120)\end{array}$ \\
\hline Mother university x Father university & & & & & & \\
\hline No, Yes & & $\begin{array}{l}0.107 \\
(0.0899)\end{array}$ & $\begin{array}{l}0.0557 \\
(0.0945)\end{array}$ & $\begin{array}{l}0.149 \\
(0.126)\end{array}$ & $\begin{array}{l}0.101 \\
(0.0899)\end{array}$ & $\begin{array}{l}0.254 \\
(0.192)\end{array}$ \\
\hline Yes, No & & $\begin{array}{l}0.171^{* * *} \\
(0.0529)\end{array}$ & $\begin{array}{l}0.153^{* * *} \\
(0.0548)\end{array}$ & $\begin{array}{l}0.118^{* *} \\
(0.0589)\end{array}$ & $\begin{array}{l}0.176^{* * *} \\
(0.0533)\end{array}$ & $\begin{array}{l}0.402^{* * *} \\
(0.113)\end{array}$ \\
\hline Yes, Yes & & $\begin{array}{l}0.195^{* * *} \\
(0.0557)\end{array}$ & $\begin{array}{l}0.190^{* * *} \\
(0.0589)\end{array}$ & $\begin{array}{l}0.222^{* * *} \\
(0.0645)\end{array}$ & $\begin{array}{l}0.202^{* * *} \\
(0.0558)\end{array}$ & $\begin{array}{l}0.410^{* * * *} \\
(0.118)\end{array}$ \\
\hline Mother stop working $\mathrm{x}$ Father stop working & & & & & & \\
\hline No, Yes & & $\begin{array}{l}-0.0642 \\
(0.0658)\end{array}$ & $\begin{array}{l}-0.0865 \\
(0.0664)\end{array}$ & $\begin{array}{l}-0.129^{*} \\
(0.0708)\end{array}$ & $\begin{array}{l}-0.0632 \\
(0.0667)\end{array}$ & $\begin{array}{l}-0.207 \\
(0.144)\end{array}$ \\
\hline Yes, No & & $\begin{array}{l}0.000288 \\
(0.0608)\end{array}$ & $\begin{array}{l}0.00219 \\
(0.0644)\end{array}$ & $\begin{array}{l}-0.0466 \\
(0.0731)\end{array}$ & $\begin{array}{l}-0.00360 \\
(0.0602)\end{array}$ & $\begin{array}{l}-0.0114 \\
(0.131)\end{array}$ \\
\hline Yes, Yes & & $\begin{array}{l}-0.0785 \\
(0.0723)\end{array}$ & $\begin{array}{l}-0.0798 \\
(0.0780)\end{array}$ & $\begin{array}{l}-0.0882 \\
(0.0954)\end{array}$ & $\begin{array}{l}-0.0851 \\
(0.0736)\end{array}$ & $\begin{array}{l}-0.135 \\
(0.146)\end{array}$ \\
\hline Mother switched to smart working & & $\begin{array}{l}-0.135^{* *} \\
(0.0587)\end{array}$ & $\begin{array}{l}-0.122^{* *} \\
(0.0620)\end{array}$ & $\begin{array}{l}-0.207^{* * *} \\
(0.0775)\end{array}$ & $\begin{array}{l}-0.136^{* *} \\
(0.0589)\end{array}$ & $\begin{array}{l}-0.332^{* * *} \\
(0.128)\end{array}$ \\
\hline Both parents under strict lockdown & & $\begin{array}{l}0.594^{* * *} \\
(0.216)\end{array}$ & $\begin{array}{l}0.656^{* * *} \\
(0.222)\end{array}$ & $\begin{array}{l}0.795^{* *} \\
(0.384)\end{array}$ & $\begin{array}{l}0.631^{* * *} \\
(0.219)\end{array}$ & $\begin{array}{l}1.097^{* *} \\
(0.460)\end{array}$ \\
\hline Survey respondent is male & & $\begin{array}{l}-0.0166 \\
(0.0749)\end{array}$ & & $\begin{array}{l}0.00831 \\
(0.106)\end{array}$ & $\begin{array}{l}0.0245 \\
(0.0735)\end{array}$ & $\begin{array}{l}0.0937 \\
(0.151)\end{array}$ \\
\hline Date of interview & & $\begin{array}{l}-0.102^{* * *} \\
(0.0320)\end{array}$ & $\begin{array}{l}-0.0931^{* * * *} \\
(0.0354)\end{array}$ & $\begin{array}{l}-0.0855^{* *} \\
(0.0399)\end{array}$ & $\begin{array}{l}-0.109^{* * *} \\
(0.0319)\end{array}$ & $\begin{array}{l}-0.210^{* * *} \\
(0.0651)\end{array}$ \\
\hline Province FE & - & Yes & Yes & Yes & Yes & Yes \\
\hline Day of week FE & - & Yes & Yes & Yes & Yes & Yes \\
\hline Observations & 3359 & 2640 & 2465 & 2625 & 2638 & 2688 \\
\hline$R$-squared ${ }^{2}$ & 0.011 & 0.134 & 0.134 & 0.179 & 0.132 & 0.0583 \\
\hline
\end{tabular}

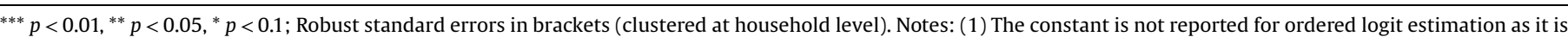

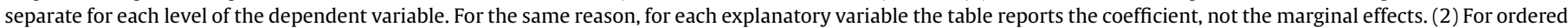
logit estimation, the pseudo $R$-squared is reported. 
Table A6

Full regression estimates for parent-child relationship.

\begin{tabular}{|c|c|c|c|c|c|c|}
\hline Personal relationship & $\begin{array}{l}\text { (1) } \\
\text { OLS }\end{array}$ & $\begin{array}{l}(2) \\
\text { OLS }\end{array}$ & $\begin{array}{l}(3) \\
\text { Female resp. }\end{array}$ & $\begin{array}{l}\text { (4) } \\
\text { Weight }\end{array}$ & $\begin{array}{l}\text { (5) } \\
\text { Cont. Var. }\end{array}$ & $\begin{array}{l}(6) \\
\text { Ologit }^{1}\end{array}$ \\
\hline Constant & $\begin{array}{l}0.130^{* * *} \\
(0.0334)\end{array}$ & $\begin{array}{l}0.149 \\
(0.182)\end{array}$ & $\begin{array}{l}0.166 \\
(0.195)\end{array}$ & $\begin{array}{l}0.178 \\
(0.247)\end{array}$ & $\begin{array}{l}0.176 \\
(0.182)\end{array}$ & \\
\hline Father main caregiver & $\begin{array}{l}0.178^{* * * *} \\
(0.0452)\end{array}$ & $\begin{array}{l}0.124^{* *} \\
(0.0534)\end{array}$ & $\begin{array}{l}0.114^{* *} \\
(0.0561)\end{array}$ & $\begin{array}{l}0.175^{* * * *} \\
(0.0634)\end{array}$ & & $\begin{array}{l}0.260^{* * * *} \\
(0.101)\end{array}$ \\
\hline Variation in father's share of childcare & & & & & $\begin{array}{l}-0.0727 \\
(0.166)\end{array}$ & \\
\hline Total parental homework hours & $\begin{array}{l}0.00179 \\
(0.00687)\end{array}$ & $\begin{array}{l}0.00950 \\
(0.00809)\end{array}$ & $\begin{array}{l}0.00762 \\
(0.00847)\end{array}$ & $\begin{array}{l}-0.000420 \\
(0.0103)\end{array}$ & $\begin{array}{l}0.0118 \\
(0.00806)\end{array}$ & $\begin{array}{l}0.0165 \\
(0.0151)\end{array}$ \\
\hline Mother's share of housework & $\begin{array}{l}0.0544 \\
(0.162)\end{array}$ & $\begin{array}{l}-0.141 \\
(0.183)\end{array}$ & $\begin{array}{l}-0.0230 \\
(0.190)\end{array}$ & $\begin{array}{l}0.0550 \\
(0.229)\end{array}$ & $\begin{array}{l}-0.174 \\
(0.192)\end{array}$ & $\begin{array}{l}-0.340 \\
(0.357)\end{array}$ \\
\hline Child is male & & $\begin{array}{l}-0.131^{* * *} \\
(0.0390)\end{array}$ & $\begin{array}{l}-0.137^{* * *} \\
(0.0409)\end{array}$ & $\begin{array}{l}-0.0993^{*} \\
(0.0566)\end{array}$ & $\begin{array}{l}-0.131^{* * *} \\
(0.0391)\end{array}$ & $\begin{array}{l}-0.253^{* * *} \\
(0.0739)\end{array}$ \\
\hline Age of child & & $\begin{array}{l}-0.0181 \\
(0.0122)\end{array}$ & $\begin{array}{l}-0.0183 \\
(0.0132)\end{array}$ & $\begin{array}{l}-0.0306^{*} \\
(0.0165)\end{array}$ & $\begin{array}{l}-0.0177 \\
(0.0122)\end{array}$ & $\begin{array}{l}-0.0386^{*} \\
(0.0227)\end{array}$ \\
\hline Distance learning hours \# kindergarden & & $\begin{array}{l}0.0339 \\
(0.0680)\end{array}$ & $\begin{array}{l}0.0229 \\
(0.0705)\end{array}$ & $\begin{array}{l}-0.00886 \\
(0.0898)\end{array}$ & $\begin{array}{l}0.0304 \\
(0.0681)\end{array}$ & $\begin{array}{l}0.116 \\
(0.130)\end{array}$ \\
\hline Distance learning hours \# Primary school & & $\begin{array}{l}0.106^{*} \\
(0.0596)\end{array}$ & $\begin{array}{l}0.0998 \\
(0.0630)\end{array}$ & $\begin{array}{l}0.112 \\
(0.0753)\end{array}$ & $\begin{array}{l}0.103^{*} \\
(0.0595)\end{array}$ & $\begin{array}{l}0.239^{* *} \\
(0.114)\end{array}$ \\
\hline Distance learning hours \# Secondary school & & $\begin{array}{l}0.323^{* * * *} \\
(0.104)\end{array}$ & $\begin{array}{l}0.329^{* * * *} \\
(0.112)\end{array}$ & $\begin{array}{l}0.311^{* *} \\
(0.138)\end{array}$ & $\begin{array}{l}0.321^{* * * *} \\
(0.104)\end{array}$ & $\begin{array}{l}0.675^{* * *} \\
(0.196)\end{array}$ \\
\hline Hours of extra curricular activities & & $\begin{array}{l}0.151^{* * *} \\
(0.0528)\end{array}$ & $\begin{array}{l}0.142^{* *} \\
(0.0558)\end{array}$ & $\begin{array}{l}0.103 \\
(0.0712)\end{array}$ & $\begin{array}{l}0.158^{* * *} \\
(0.0527)\end{array}$ & $\begin{array}{l}0.218^{* * *} \\
(0.0842)\end{array}$ \\
\hline 2 children in the household & & $\begin{array}{l}-0.0978^{*} \\
(0.0547)\end{array}$ & $\begin{array}{l}-0.107^{*} \\
(0.0569)\end{array}$ & $\begin{array}{l}-0.135^{* *} \\
(0.0682)\end{array}$ & $\begin{array}{l}-0.104^{*} \\
(0.0548)\end{array}$ & $\begin{array}{l}-0.149 \\
(0.103)\end{array}$ \\
\hline 3 children in the household & & $\begin{array}{l}-0.0610 \\
(0.0777)\end{array}$ & $\begin{array}{l}-0.0599 \\
(0.0818)\end{array}$ & $\begin{array}{l}-0.132 \\
(0.0920)\end{array}$ & $\begin{array}{l}-0.0843 \\
(0.0769)\end{array}$ & $\begin{array}{l}-0.0595 \\
(0.144)\end{array}$ \\
\hline 4 children in the household & & $\begin{array}{l}0.198 \\
(0.214)\end{array}$ & $\begin{array}{l}0.173 \\
(0.214)\end{array}$ & $\begin{array}{l}0.361 \\
(0.309)\end{array}$ & $\begin{array}{l}0.196 \\
(0.213)\end{array}$ & $\begin{array}{l}0.336 \\
(0.421)\end{array}$ \\
\hline More than 4 children in the household & & $\begin{array}{l}0.346 \\
(0.406)\end{array}$ & $\begin{array}{l}0.331 \\
(0.408)\end{array}$ & $\begin{array}{l}0.366 \\
(0.298)\end{array}$ & $\begin{array}{l}0.318 \\
(0.404)\end{array}$ & $\begin{array}{l}0.732 \\
(0.617)\end{array}$ \\
\hline At least one parent is not Italian & & $\begin{array}{l}0.147^{* *} \\
(0.0703)\end{array}$ & $\begin{array}{l}0.149^{* *} \\
(0.0739)\end{array}$ & $\begin{array}{l}0.150^{*} \\
(0.0769)\end{array}$ & $\begin{array}{l}0.139^{* *} \\
(0.0706)\end{array}$ & $\begin{array}{l}0.258^{*} \\
(0.135)\end{array}$ \\
\hline Mother university x Father university & & & & & & \\
\hline No, Yes & & $\begin{array}{l}0.0811 \\
(0.105)\end{array}$ & $\begin{array}{l}0.107 \\
(0.112)\end{array}$ & $\begin{array}{l}0.103 \\
(0.129)\end{array}$ & $\begin{array}{l}0.0789 \\
(0.105)\end{array}$ & $\begin{array}{l}0.143 \\
(0.201)\end{array}$ \\
\hline Yes, No & & $\begin{array}{l}0.0896 \\
(0.0635)\end{array}$ & $\begin{array}{l}0.104 \\
(0.0656)\end{array}$ & $\begin{array}{l}0.0615 \\
(0.0660)\end{array}$ & $\begin{array}{l}0.0986 \\
(0.0639)\end{array}$ & $\begin{array}{l}0.174 \\
(0.119)\end{array}$ \\
\hline Yes, Yes & & $\begin{array}{l}0.128^{* *} \\
(0.0615)\end{array}$ & $\begin{array}{l}0.148^{* *} \\
(0.0642)\end{array}$ & $\begin{array}{l}0.133^{*} \\
(0.0748)\end{array}$ & $\begin{array}{l}0.146^{* *} \\
(0.0614)\end{array}$ & $\begin{array}{l}0.253^{* *} \\
(0.115)\end{array}$ \\
\hline Mother stop working $\mathrm{x}$ Father stop working & & & & & & \\
\hline No, Yes & & $\begin{array}{l}-0.118^{*} \\
(0.0709)\end{array}$ & $\begin{array}{l}-0.130^{*} \\
(0.0725)\end{array}$ & $\begin{array}{l}-0.0250 \\
(0.0855)\end{array}$ & $\begin{array}{c}-0.0983 \\
(0.0711)\end{array}$ & $\begin{array}{l}-0.248^{*} \\
(0.135)\end{array}$ \\
\hline Yes, No & & $\begin{array}{l}0.0776 \\
(0.0692)\end{array}$ & $\begin{array}{l}0.0869 \\
(0.0725)\end{array}$ & $\begin{array}{l}0.195^{* *} \\
(0.0853)\end{array}$ & $\begin{array}{l}0.0560 \\
(0.0702)\end{array}$ & $\begin{array}{l}0.122 \\
(0.129)\end{array}$ \\
\hline Yes, Yes & & $\begin{array}{l}-0.0108 \\
(0.0931)\end{array}$ & $\begin{array}{l}-0.00458 \\
(0.100)\end{array}$ & $\begin{array}{l}0.0841 \\
(0.115)\end{array}$ & $\begin{array}{l}-0.00568 \\
(0.0935)\end{array}$ & $\begin{array}{c}-0.103 \\
(0.173)\end{array}$ \\
\hline Mother switched to smart working & & $\begin{array}{l}-0.0627 \\
(0.0693)\end{array}$ & $\begin{array}{l}-0.0735 \\
(0.0732)\end{array}$ & $\begin{array}{l}-0.0777 \\
(0.0839)\end{array}$ & $\begin{array}{l}-0.0609 \\
(0.0692)\end{array}$ & $\begin{array}{l}-0.121 \\
(0.134)\end{array}$ \\
\hline Both parents under strict lockdown & & $\begin{array}{l}1.031^{* * *} \\
(0.186)\end{array}$ & $\begin{array}{l}1.127^{* * *} \\
(0.165)\end{array}$ & $\begin{array}{l}1.071^{* * *} \\
(0.356)\end{array}$ & $\begin{array}{l}1.043^{* * * *} \\
(0.184)\end{array}$ & $\begin{array}{l}2.052^{* * * *} \\
(0.401)\end{array}$ \\
\hline Survey respondent is male & & $\begin{array}{l}-0.0172 \\
(0.0862)\end{array}$ & & $\begin{array}{l}0.135 \\
(0.138)\end{array}$ & $\begin{array}{l}0.0145 \\
(0.0865)\end{array}$ & $\begin{array}{l}-0.00603 \\
(0.160)\end{array}$ \\
\hline Date of interview & & $\begin{array}{l}-0.110^{* * *} \\
(0.0334)\end{array}$ & $\begin{array}{l}-0.115^{* * *} \\
(0.0362)\end{array}$ & $\begin{array}{l}-0.102^{* *} \\
(0.0464)\end{array}$ & $\begin{array}{l}-0.114^{* * *} \\
(0.0334)\end{array}$ & $\begin{array}{l}-0.222^{\text {*** }} \\
(0.0618)\end{array}$ \\
\hline Province FE & - & Yes & Yes & Yes & Yes & Yes \\
\hline Day of week FE & - & Yes & Yes & Yes & Yes & Yes \\
\hline Observations & 3375 & 2648 & 2473 & 2633 & 2646 & 2696 \\
\hline$R$-squared ${ }^{2}$ & 0.007 & 0.089 & 0.092 & 0.129 & 0.086 & 0.0339 \\
\hline
\end{tabular}

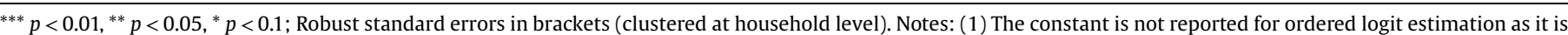

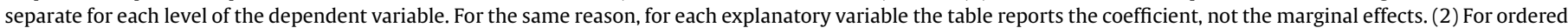
logit estimation, the pseudo $R$-squared is reported. 
Table A7

Full regression estimates for children's hours of TV.

\begin{tabular}{|c|c|c|c|c|c|c|}
\hline Hours of TV & $\begin{array}{l}\text { (1) } \\
\text { OLS }\end{array}$ & $\begin{array}{l}(2) \\
\text { OLS }\end{array}$ & $\begin{array}{l}\text { (3) } \\
\text { Female resp. }\end{array}$ & $\begin{array}{l}\text { (4) } \\
\text { Weight }\end{array}$ & $\begin{array}{l}\text { (5) } \\
\text { Cont. Var. }\end{array}$ & $\begin{array}{l}(6) \\
\text { Ologit }^{1}\end{array}$ \\
\hline Constant & $\begin{array}{l}1.492^{* * *} \\
(0.0518)\end{array}$ & $\begin{array}{l}1.907^{* * *} \\
(0.258)\end{array}$ & $\begin{array}{l}1.931^{* * *} \\
(0.269)\end{array}$ & $\begin{array}{l}2.256^{* * * *} \\
(0.464)\end{array}$ & $\begin{array}{l}1.887^{* * *} \\
(0.258)\end{array}$ & \\
\hline Father main caregiver & $\begin{array}{l}-0.156^{* *} \\
(0.0652)\end{array}$ & $\begin{array}{l}-0.147^{*} \\
(0.0753)\end{array}$ & $\begin{array}{l}-0.132^{*} \\
(0.0782)\end{array}$ & $\begin{array}{l}0.00156 \\
(0.105)\end{array}$ & & $\begin{array}{l}-0.220^{* *} \\
(0.0968)\end{array}$ \\
\hline Variation in father's share of childcare & & & & & $\begin{array}{l}-0.428^{*} \\
(0.220)\end{array}$ & \\
\hline Total parental homework hours & $\begin{array}{l}0.0256^{* *} \\
(0.0101)\end{array}$ & $\begin{array}{l}0.0216^{*} \\
(0.0126)\end{array}$ & $\begin{array}{l}0.0182 \\
(0.0131)\end{array}$ & $\begin{array}{l}0.00379 \\
(0.0195)\end{array}$ & $\begin{array}{l}0.0209^{*} \\
(0.0125)\end{array}$ & $\begin{array}{l}0.0388^{* *} \\
(0.0161)\end{array}$ \\
\hline Mother's share of housework & $\begin{array}{l}0.455^{*} \\
(0.252)\end{array}$ & $\begin{array}{l}0.633^{* *} \\
(0.297)\end{array}$ & $\begin{array}{l}0.636^{* *} \\
(0.311)\end{array}$ & $\begin{array}{l}0.784 \\
(0.502)\end{array}$ & $\begin{array}{l}0.533^{*} \\
(0.306)\end{array}$ & $\begin{array}{l}0.764^{* *} \\
(0.359)\end{array}$ \\
\hline Child is male & & $\begin{array}{l}0.0242 \\
(0.0611)\end{array}$ & $\begin{array}{l}0.0274 \\
(0.0633)\end{array}$ & $\begin{array}{l}-0.0302 \\
(0.0916)\end{array}$ & $\begin{array}{l}0.0223 \\
(0.0611)\end{array}$ & $\begin{array}{l}0.140^{*} \\
(0.0783)\end{array}$ \\
\hline Age of child & & $\begin{array}{l}-0.0134 \\
(0.0186)\end{array}$ & $\begin{array}{l}-0.0181 \\
(0.0195)\end{array}$ & $\begin{array}{l}-0.0654^{* *} \\
(0.0305)\end{array}$ & $\begin{array}{l}-0.0137 \\
(0.0186)\end{array}$ & $\begin{array}{l}0.0112 \\
(0.0225)\end{array}$ \\
\hline Distance learning hours \# kindergarden & & $\begin{array}{l}-0.128 \\
(0.101)\end{array}$ & $\begin{array}{l}-0.142 \\
(0.104)\end{array}$ & $\begin{array}{l}-0.365^{* *} \\
(0.144)\end{array}$ & $\begin{array}{l}-0.133 \\
(0.100)\end{array}$ & $\begin{array}{l}-0.173 \\
(0.128)\end{array}$ \\
\hline Distance learning hours \# Primary school & & $\begin{array}{l}0.146^{*} \\
(0.0883)\end{array}$ & $\begin{array}{l}0.152^{*} \\
(0.0907)\end{array}$ & $\begin{array}{l}0.181 \\
(0.136)\end{array}$ & $\begin{array}{l}0.155^{*} \\
(0.0883)\end{array}$ & $\begin{array}{l}0.163 \\
(0.110)\end{array}$ \\
\hline Distance learning hours \# Secondary school & & $\begin{array}{l}0.0621 \\
(0.160)\end{array}$ & $\begin{array}{l}0.0398 \\
(0.167)\end{array}$ & $\begin{array}{l}0.225 \\
(0.275)\end{array}$ & $\begin{array}{l}0.0726 \\
(0.160)\end{array}$ & $\begin{array}{l}0.0262 \\
(0.200)\end{array}$ \\
\hline Hours of extra curricular activities & & $\begin{array}{l}-0.400^{* * *} \\
(0.0830)\end{array}$ & $\begin{array}{l}-0.432^{* * *} \\
(0.0867)\end{array}$ & $\begin{array}{l}-0.434^{* * *} \\
(0.129)\end{array}$ & $\begin{array}{l}-0.395^{* * *} \\
(0.0832)\end{array}$ & $\begin{array}{l}-0.518^{* * *} \\
(0.0968)\end{array}$ \\
\hline 2 children in the household & & $\begin{array}{l}-0.0477 \\
(0.0847)\end{array}$ & $\begin{array}{l}-0.0547 \\
(0.0875)\end{array}$ & $\begin{array}{l}0.00963 \\
(0.125)\end{array}$ & $\begin{array}{l}-0.0480 \\
(0.0848)\end{array}$ & $\begin{array}{l}-0.111 \\
(0.104)\end{array}$ \\
\hline 3 children in the household & & $\begin{array}{l}-0.124 \\
(0.118)\end{array}$ & $\begin{array}{l}-0.117 \\
(0.124)\end{array}$ & $\begin{array}{l}-0.0645 \\
(0.162)\end{array}$ & $\begin{array}{l}-0.115 \\
(0.118)\end{array}$ & $\begin{array}{l}-0.256^{*} \\
(0.149)\end{array}$ \\
\hline 4 children in the household & & $\begin{array}{l}0.249 \\
(0.277)\end{array}$ & $\begin{array}{l}0.242 \\
(0.276)\end{array}$ & $\begin{array}{l}0.370 \\
(0.338)\end{array}$ & $\begin{array}{l}0.241 \\
(0.274)\end{array}$ & $\begin{array}{l}0.320 \\
(0.425)\end{array}$ \\
\hline More than 4 children in the household & & $\begin{array}{l}0.520 \\
(0.671)\end{array}$ & $\begin{array}{l}0.608 \\
(0.642)\end{array}$ & $\begin{array}{l}0.536 \\
(0.760)\end{array}$ & $\begin{array}{l}0.590 \\
(0.682)\end{array}$ & $\begin{array}{l}0.912 \\
(0.770)\end{array}$ \\
\hline At least one parent is not Italian & & $\begin{array}{l}0.0370 \\
(0.121)\end{array}$ & $\begin{array}{l}0.0327 \\
(0.127)\end{array}$ & $\begin{array}{l}0.148 \\
(0.134)\end{array}$ & $\begin{array}{l}0.0337 \\
(0.121)\end{array}$ & $\begin{array}{l}0.0803 \\
(0.158)\end{array}$ \\
\hline Mother university $\mathrm{x}$ Father university & & & & & & \\
\hline No, Yes & & $\begin{array}{l}-0.0358 \\
(0.168)\end{array}$ & $\begin{array}{l}0.0350 \\
(0.170)\end{array}$ & $\begin{array}{l}0.153 \\
(0.157)\end{array}$ & $\begin{array}{l}-0.0352 \\
(0.167)\end{array}$ & $\begin{array}{l}-0.0487 \\
(0.208)\end{array}$ \\
\hline Yes, No & & $\begin{array}{l}-0.0323 \\
(0.0949)\end{array}$ & $\begin{array}{l}-0.0274 \\
(0.0973)\end{array}$ & $\begin{array}{l}0.0159 \\
(0.114)\end{array}$ & $\begin{array}{l}-0.0398 \\
(0.0954)\end{array}$ & $\begin{array}{l}-0.0930 \\
(0.125)\end{array}$ \\
\hline Yes, Yes & & $\begin{array}{l}-0.208^{* *} \\
(0.0909)\end{array}$ & $\begin{array}{l}-0.198^{* *} \\
(0.0938)\end{array}$ & $\begin{array}{l}-0.228^{* *} \\
(0.112)\end{array}$ & $\begin{array}{l}-0.213^{* *} \\
(0.0921)\end{array}$ & $\begin{array}{l}-0.337^{* * *} \\
(0.117)\end{array}$ \\
\hline Mother stop working $\mathrm{x}$ Father stop working & & & & & & \\
\hline No, Yes & & $\begin{array}{l}0.102 \\
(0.117)\end{array}$ & $\begin{array}{l}0.117 \\
(0.119)\end{array}$ & $\begin{array}{l}0.152 \\
(0.153)\end{array}$ & $\begin{array}{l}0.108 \\
(0.119)\end{array}$ & $\begin{array}{l}0.220 \\
(0.149)\end{array}$ \\
\hline Yes, No & & $\begin{array}{l}-0.107 \\
(0.0979)\end{array}$ & $\begin{array}{l}-0.0882 \\
(0.102)\end{array}$ & $\begin{array}{l}0.119 \\
(0.162)\end{array}$ & $\begin{array}{l}-0.111 \\
(0.0981)\end{array}$ & $\begin{array}{l}-0.0976 \\
(0.121)\end{array}$ \\
\hline Yes, Yes & & $\begin{array}{l}0.206 \\
(0.127)\end{array}$ & $\begin{array}{l}0.247^{*} \\
(0.131)\end{array}$ & $\begin{array}{l}0.296^{*} \\
(0.163)\end{array}$ & $\begin{array}{l}0.216^{*} \\
(0.127)\end{array}$ & $\begin{array}{l}0.249 \\
(0.164)\end{array}$ \\
\hline Mother switched to smart working & & $\begin{array}{l}-0.0556 \\
(0.111)\end{array}$ & $\begin{array}{l}-0.0852 \\
(0.115)\end{array}$ & $\begin{array}{l}0.194 \\
(0.174)\end{array}$ & $\begin{array}{l}-0.0532 \\
(0.111)\end{array}$ & $\begin{array}{l}-0.0619 \\
(0.144)\end{array}$ \\
\hline Both parents under strict lockdown & & $\begin{array}{l}-0.0461 \\
(0.296)\end{array}$ & $\begin{array}{l}0.0164 \\
(0.310)\end{array}$ & $\begin{array}{l}0.688 \\
(0.536)\end{array}$ & $\begin{array}{l}-0.0870 \\
(0.298)\end{array}$ & $\begin{array}{l}-0.396 \\
(0.349)\end{array}$ \\
\hline Survey respondent is male & & $\begin{array}{l}-0.171 \\
(0.162)\end{array}$ & & $\begin{array}{l}-0.280 \\
(0.221)\end{array}$ & $\begin{array}{l}-0.212 \\
(0.164)\end{array}$ & $\begin{array}{l}-0.211 \\
(0.177)\end{array}$ \\
\hline Date of interview & & $\begin{array}{l}0.121^{* *} \\
(0.0610)\end{array}$ & $\begin{array}{l}0.0953 \\
(0.0641)\end{array}$ & $\begin{array}{l}0.126 \\
(0.0981)\end{array}$ & $\begin{array}{l}0.128^{* *} \\
(0.0599)\end{array}$ & $\begin{array}{l}0.129 * \\
(0.0734)\end{array}$ \\
\hline Province FE & - & Yes & Yes & Yes & Yes & Yes \\
\hline Day of week FE & - & Yes & Yes & Yes & Yes & Yes \\
\hline Observations & 3140 & 2470 & 2333 & 2455 & 2468 & 2511 \\
\hline$R$-squared ${ }^{2}$ & 0.007 & 0.094 & 0.096 & 0.127 & 0.094 & 0.0326 \\
\hline
\end{tabular}

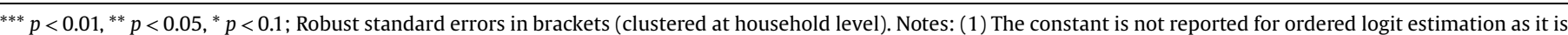

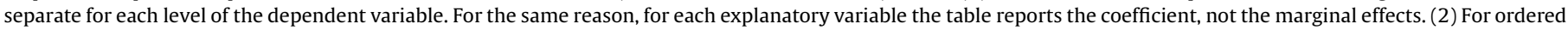
logit estimation, the pseudo $R$-squared is reported. 
Table A8

Full regression estimates for children's reading hours.

\begin{tabular}{|c|c|c|c|c|c|c|}
\hline Reading hours & $\begin{array}{l}(1) \\
\text { OLS }\end{array}$ & $\begin{array}{l}(2) \\
\text { OLS }\end{array}$ & $\begin{array}{l}(3) \\
\text { Female resp. }\end{array}$ & $\begin{array}{l}\text { (4) } \\
\text { Weight }\end{array}$ & $\begin{array}{l}\text { (5) } \\
\text { Cont. Var. }\end{array}$ & $\begin{array}{l}(6) \\
\text { Ologit }^{1}\end{array}$ \\
\hline Constant & $\begin{array}{l}0.152^{* * * *} \\
(0.0311)\end{array}$ & $\begin{array}{l}0.244 \\
(0.152)\end{array}$ & $\begin{array}{l}0.258 \\
(0.160)\end{array}$ & $\begin{array}{l}0.317 \\
(0.215)\end{array}$ & $\begin{array}{l}0.242 \\
(0.152)\end{array}$ & \\
\hline Father main caregiver & $\begin{array}{l}0.0273 \\
(0.0373)\end{array}$ & $\begin{array}{l}-0.0166 \\
(0.0464)\end{array}$ & $\begin{array}{l}-0.0350 \\
(0.0474)\end{array}$ & $\begin{array}{l}0.0239 \\
(0.0549)\end{array}$ & & $\begin{array}{l}-0.0910 \\
(0.112)\end{array}$ \\
\hline Variation in father's share of childcare & & & & & $\begin{array}{l}-0.0538 \\
(0.140)\end{array}$ & \\
\hline Total parental homework hours & $\begin{array}{l}0.0240^{* * *} \\
(0.00649)\end{array}$ & $\begin{array}{l}0.00970 \\
(0.00795)\end{array}$ & $\begin{array}{l}0.0108 \\
(0.00838)\end{array}$ & $\begin{array}{l}0.0173 \\
(0.0107)\end{array}$ & $\begin{array}{l}0.00964 \\
(0.00790)\end{array}$ & $\begin{array}{l}0.0257 \\
(0.0189)\end{array}$ \\
\hline Mother's share of housework & $\begin{array}{l}0.119 \\
(0.171)\end{array}$ & $\begin{array}{l}-0.00953 \\
(0.203)\end{array}$ & $\begin{array}{l}-0.0169 \\
(0.210)\end{array}$ & $\begin{array}{l}0.122 \\
(0.218)\end{array}$ & $\begin{array}{l}-0.0201 \\
(0.204)\end{array}$ & $\begin{array}{l}0.103 \\
(0.381)\end{array}$ \\
\hline Child is male & & $\begin{array}{l}-0.0423 \\
(0.0367)\end{array}$ & $\begin{array}{l}-0.0402 \\
(0.0383)\end{array}$ & $\begin{array}{l}-0.0699 \\
(0.0487)\end{array}$ & $\begin{array}{l}-0.0425 \\
(0.0368)\end{array}$ & $\begin{array}{l}-0.174^{* *} \\
(0.0853)\end{array}$ \\
\hline Age of child & & $\begin{array}{l}-0.00978 \\
(0.0111)\end{array}$ & $\begin{array}{l}-0.0129 \\
(0.0117)\end{array}$ & $\begin{array}{l}-0.0203 \\
(0.0147)\end{array}$ & $\begin{array}{l}-0.00985 \\
(0.0112)\end{array}$ & $\begin{array}{l}-0.0491 * \\
(0.0271)\end{array}$ \\
\hline Distance learning hours \# kindergarden & & $\begin{array}{l}0.00286 \\
(0.0633)\end{array}$ & $\begin{array}{l}-0.0229 \\
(0.0651)\end{array}$ & $\begin{array}{l}0.136 \\
(0.0968)\end{array}$ & $\begin{array}{l}0.00208 \\
(0.0634)\end{array}$ & $\begin{array}{l}-0.0705 \\
(0.153)\end{array}$ \\
\hline Distance learning hours \# Primary school & & $\begin{array}{l}-0.0286 \\
(0.0505)\end{array}$ & $\begin{array}{l}-0.0265 \\
(0.0528)\end{array}$ & $\begin{array}{l}0.0656 \\
(0.0770)\end{array}$ & $\begin{array}{l}-0.0273 \\
(0.0505)\end{array}$ & $\begin{array}{l}-0.00522 \\
(0.128)\end{array}$ \\
\hline Distance learning hours \# Secondary school & & $\begin{array}{l}-0.0798 \\
(0.0987)\end{array}$ & $\begin{array}{l}-0.0569 \\
(0.106)\end{array}$ & $\begin{array}{l}0.00707 \\
(0.147)\end{array}$ & $\begin{array}{l}-0.0782 \\
(0.0992)\end{array}$ & $\begin{array}{l}-0.0360 \\
(0.233)\end{array}$ \\
\hline Hours of extra curricular activities & & $\begin{array}{l}0.0649 \\
(0.0443)\end{array}$ & $\begin{array}{l}0.101^{* *} \\
(0.0468)\end{array}$ & $\begin{array}{l}0.0765 \\
(0.0684)\end{array}$ & $\begin{array}{l}0.0657 \\
(0.0444)\end{array}$ & $\begin{array}{l}0.0715 \\
(0.0986)\end{array}$ \\
\hline 2 children in the household & & $\begin{array}{l}-0.0467 \\
(0.0471)\end{array}$ & $\begin{array}{l}-0.0540 \\
(0.0482)\end{array}$ & $\begin{array}{l}-0.0677 \\
(0.0598)\end{array}$ & $\begin{array}{l}-0.0471 \\
(0.0471)\end{array}$ & $\begin{array}{l}-0.165 \\
(0.112)\end{array}$ \\
\hline 3 children in the household & & $\begin{array}{l}-0.0697 \\
(0.0625)\end{array}$ & $\begin{array}{l}-0.0881 \\
(0.0649)\end{array}$ & $\begin{array}{l}-0.00170 \\
(0.0797)\end{array}$ & $\begin{array}{l}-0.0690 \\
(0.0620)\end{array}$ & $\begin{array}{l}-0.244 \\
(0.162)\end{array}$ \\
\hline 4 children in the household & & $\begin{array}{l}-0.176 \\
(0.144)\end{array}$ & $\begin{array}{l}-0.195 \\
(0.141)\end{array}$ & $\begin{array}{l}-0.189 \\
(0.164)\end{array}$ & $\begin{array}{l}-0.178 \\
(0.143)\end{array}$ & $\begin{array}{l}-0.716^{* *} \\
(0.297)\end{array}$ \\
\hline More than 4 children in the household & & $\begin{array}{l}0.273 \\
(0.249)\end{array}$ & $\begin{array}{l}0.264 \\
(0.252)\end{array}$ & $\begin{array}{l}0.450^{* *} \\
(0.224)\end{array}$ & $\begin{array}{l}0.281 \\
(0.250)\end{array}$ & $\begin{array}{l}0.478 \\
(0.551)\end{array}$ \\
\hline At least one parent is not Italian & & $\begin{array}{l}0.118 \\
(0.0724)\end{array}$ & $\begin{array}{l}0.121 \\
(0.0746)\end{array}$ & $\begin{array}{l}0.0169 \\
(0.0686)\end{array}$ & $\begin{array}{l}0.117 \\
(0.0729)\end{array}$ & $\begin{array}{l}0.151 \\
(0.154)\end{array}$ \\
\hline \multicolumn{7}{|l|}{ Mother university x Father university } \\
\hline No, Yes & & $\begin{array}{l}-0.118 \\
(0.147)\end{array}$ & $\begin{array}{l}-0.114 \\
(0.158)\end{array}$ & $\begin{array}{l}-0.200^{*} \\
(0.119)\end{array}$ & $\begin{array}{c}-0.118 \\
(0.147)\end{array}$ & $\begin{array}{l}-0.0348 \\
(0.270)\end{array}$ \\
\hline Yes, No & & $\begin{array}{l}0.0840 \\
(0.0525)\end{array}$ & $\begin{array}{l}0.0878 \\
(0.0538)\end{array}$ & $\begin{array}{l}0.111^{*} \\
(0.0566)\end{array}$ & $\begin{array}{l}0.0833 \\
(0.0526)\end{array}$ & $\begin{array}{l}0.190 \\
(0.130)\end{array}$ \\
\hline Yes, Yes & & $\begin{array}{l}0.186^{* * *} \\
(0.0540)\end{array}$ & $\begin{array}{l}0.189^{* * *} \\
(0.0556)\end{array}$ & $\begin{array}{l}0.200^{* * *} \\
(0.0699)\end{array}$ & $\begin{array}{l}0.186^{* * *} \\
(0.0543)\end{array}$ & $\begin{array}{l}0.470^{* * *} \\
(0.130)\end{array}$ \\
\hline \multicolumn{7}{|l|}{ Mother stop working $\mathrm{x}$ Father stop working } \\
\hline No, Yes & & $\begin{array}{c}-0.0188 \\
(0.0582)\end{array}$ & $\begin{array}{l}-0.0150 \\
(0.0592)\end{array}$ & $\begin{array}{l}0.0328 \\
(0.0750)\end{array}$ & $\begin{array}{l}-0.0176 \\
(0.0589)\end{array}$ & $\begin{array}{l}-0.0557 \\
(0.146)\end{array}$ \\
\hline Yes, No & & $\begin{array}{l}-0.0399 \\
(0.0586)\end{array}$ & $\begin{array}{l}-0.0478 \\
(0.0628)\end{array}$ & $\begin{array}{l}0.0867 \\
(0.0757)\end{array}$ & $\begin{array}{l}-0.0405 \\
(0.0585)\end{array}$ & $\begin{array}{l}-0.108 \\
(0.134)\end{array}$ \\
\hline Yes, Yes & & $\begin{array}{c}-0.0544 \\
(0.0744)\end{array}$ & $\begin{array}{l}-0.0428 \\
(0.0783)\end{array}$ & $\begin{array}{l}-0.00524 \\
(0.0859)\end{array}$ & $\begin{array}{l}-0.0531 \\
(0.0747)\end{array}$ & $\begin{array}{l}-0.241 \\
(0.177)\end{array}$ \\
\hline Mother switched to smart working & & $\begin{array}{l}-0.0182 \\
(0.0627)\end{array}$ & $\begin{array}{l}-0.0415 \\
(0.0650)\end{array}$ & $\begin{array}{l}-0.0597 \\
(0.0928)\end{array}$ & $\begin{array}{l}-0.0178 \\
(0.0630)\end{array}$ & $\begin{array}{l}0.00436 \\
(0.156)\end{array}$ \\
\hline Both parents under strict lockdown & & $\begin{array}{l}0.646^{* *} \\
(0.275)\end{array}$ & $\begin{array}{l}0.691^{* *} \\
(0.287)\end{array}$ & $\begin{array}{l}0.116 \\
(0.366)\end{array}$ & $\begin{array}{l}0.641^{* *} \\
(0.275)\end{array}$ & $\begin{array}{l}1.149^{* *} \\
(0.510)\end{array}$ \\
\hline Survey respondent is male & & $\begin{array}{l}0.0467 \\
(0.0811)\end{array}$ & & $\begin{array}{l}0.0700 \\
(0.0828)\end{array}$ & $\begin{array}{l}0.0427 \\
(0.0795)\end{array}$ & $\begin{array}{l}0.0856 \\
(0.181)\end{array}$ \\
\hline Date of interview & & $\begin{array}{l}-0.0629^{*} \\
(0.0342)\end{array}$ & $\begin{array}{l}-0.0889^{* *} \\
(0.0369)\end{array}$ & $\begin{array}{l}-0.0166 \\
(0.0459)\end{array}$ & $\begin{array}{l}-0.0620^{*} \\
(0.0342)\end{array}$ & $\begin{array}{l}-0.144^{*} \\
(0.0798)\end{array}$ \\
\hline Province FE & - & Yes & Yes & Yes & Yes & Yes \\
\hline Day of week FE & - & Yes & Yes & Yes & Yes & Yes \\
\hline $\begin{array}{l}\text { Observations } \\
R \text {-sauared }\end{array}$ & 3107 & 2441 & 2306 & 2426 & 2439 & 2482 \\
\hline$R$-squared ${ }^{2}$ & 0.008 & 0.083 & 0.088 & 0.124 & 0.083 & 0.0388 \\
\hline
\end{tabular}

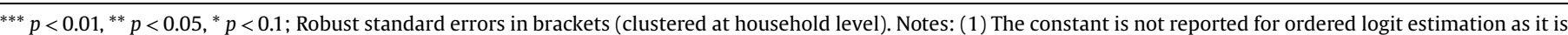

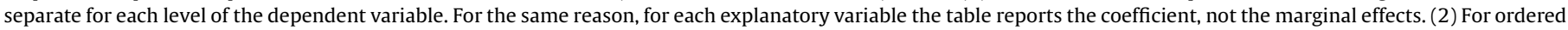
logit estimation, the pseudo $R$-squared is reported. 
Table A9

Full regression estimates for children's educational progress.

\begin{tabular}{|c|c|c|c|c|c|c|}
\hline Educational progress & $\begin{array}{l}(1) \\
\text { OLS }\end{array}$ & $\begin{array}{l}(2) \\
\text { OLS }\end{array}$ & $\begin{array}{l}(3) \\
\text { Female resp. }\end{array}$ & $\begin{array}{l}(4) \\
\text { Weight }\end{array}$ & $\begin{array}{l}\text { (5) } \\
\text { Cont. Var. }\end{array}$ & $\begin{array}{l}(6) \\
\text { Ologit }^{1}\end{array}$ \\
\hline Constant & $\begin{array}{l}-4.787^{* * * *} \\
(0.0952)\end{array}$ & $\begin{array}{l}-8.786^{* * * *} \\
(0.453)\end{array}$ & $\begin{array}{l}-8.919^{* * *} \\
(0.464)\end{array}$ & $\begin{array}{l}-8.416^{* * *} \\
(0.698)\end{array}$ & $\begin{array}{l}-8.774^{* * *} \\
(0.454)\end{array}$ & \\
\hline Father main caregiver & $\begin{array}{l}0.000515 \\
(0.134)\end{array}$ & $\begin{array}{l}0.195 \\
(0.127)\end{array}$ & $\begin{array}{l}0.203 \\
(0.132)\end{array}$ & $\begin{array}{l}0.360^{* *} \\
(0.180)\end{array}$ & & $\begin{array}{l}0.137 \\
(0.0976)\end{array}$ \\
\hline Variation in father's share of childcare & & & & & $\begin{array}{l}0.251 \\
(0.378)\end{array}$ & \\
\hline Total parental homework hours & $\begin{array}{l}-0.126^{* * *} \\
(0.0198)\end{array}$ & $\begin{array}{l}-0.0566^{* * *} \\
(0.0186)\end{array}$ & $\begin{array}{l}-0.0629^{* * *} \\
(0.0191)\end{array}$ & $\begin{array}{l}-0.0709^{* *} \\
(0.0295)\end{array}$ & $\begin{array}{l}-0.0542^{* * *} \\
(0.0185)\end{array}$ & $\begin{array}{l}-0.0412^{* * *} \\
(0.0142)\end{array}$ \\
\hline Mother's share of housework & $\begin{array}{l}0.176 \\
(0.472)\end{array}$ & $\begin{array}{l}0.301 \\
(0.440)\end{array}$ & $\begin{array}{l}0.206 \\
(0.460)\end{array}$ & $\begin{array}{l}0.0923 \\
(0.656)\end{array}$ & $\begin{array}{l}0.256 \\
(0.452)\end{array}$ & $\begin{array}{l}0.197 \\
(0.344)\end{array}$ \\
\hline Child is male & & $\begin{array}{l}-0.248^{* * *} \\
(0.0963)\end{array}$ & $\begin{array}{l}-0.243^{* *} \\
(0.0997)\end{array}$ & $\begin{array}{l}-0.338^{* *} \\
(0.144)\end{array}$ & $\begin{array}{l}-0.244^{* *} \\
(0.0965)\end{array}$ & $\begin{array}{l}-0.204^{* * *} \\
(0.0724)\end{array}$ \\
\hline Age of child & & $\begin{array}{l}0.230^{* * *} \\
(0.0295)\end{array}$ & $\begin{array}{l}0.232^{* * *} \\
(0.0318)\end{array}$ & $\begin{array}{l}0.213^{* * *} \\
(0.0469)\end{array}$ & $\begin{array}{l}0.234^{* * *} \\
(0.0294)\end{array}$ & $\begin{array}{l}0.173^{* * *} \\
(0.0221)\end{array}$ \\
\hline Distance learning hours \# kindergarden & & $\begin{array}{l}1.735^{* * *} \\
(0.190)\end{array}$ & $\begin{array}{l}1.669 * * * \\
(0.195)\end{array}$ & $\begin{array}{l}1.672^{* * *} \\
(0.260)\end{array}$ & $\begin{array}{l}1.741^{* * *} \\
(0.190)\end{array}$ & $\begin{array}{l}1.348^{* * *} \\
(0.142)\end{array}$ \\
\hline Distance learning hours \# Primary school & & $\begin{array}{l}2.465^{* * *} \\
(0.160)\end{array}$ & $\begin{array}{l}2.452^{* * *} \\
(0.169)\end{array}$ & $\begin{array}{l}2.195^{* * *} \\
(0.249)\end{array}$ & $\begin{array}{l}2.440^{* * *} \\
(0.160)\end{array}$ & $\begin{array}{l}1.842^{* * *} \\
(0.126)\end{array}$ \\
\hline Distance learning hours \# Secondary school & & $\begin{array}{l}1.806^{* * *} \\
(0.259)\end{array}$ & $\begin{array}{l}1.817^{* * *} \\
(0.281)\end{array}$ & $\begin{array}{l}1.721^{* * *} \\
(0.441)\end{array}$ & $\begin{array}{l}1.771^{* * * *} \\
(0.259)\end{array}$ & $\begin{array}{l}1.309^{* * *} \\
(0.190)\end{array}$ \\
\hline Hours of extra curricular activities & & $\begin{array}{l}0.258^{* *} \\
(0.118)\end{array}$ & $\begin{array}{l}0.330^{* * *} \\
(0.123)\end{array}$ & $\begin{array}{l}0.0945 \\
(0.188)\end{array}$ & $\begin{array}{l}0.256^{* *} \\
(0.119)\end{array}$ & $\begin{array}{l}0.0901 \\
(0.0790)\end{array}$ \\
\hline 2 children in the household & & $\begin{array}{l}0.113 \\
(0.132)\end{array}$ & $\begin{array}{l}0.114 \\
(0.137)\end{array}$ & $\begin{array}{l}0.227 \\
(0.179)\end{array}$ & $\begin{array}{l}0.118 \\
(0.132)\end{array}$ & $\begin{array}{l}0.0801 \\
(0.0991)\end{array}$ \\
\hline 3 children in the household & & $\begin{array}{l}0.529^{* * *} \\
(0.187)\end{array}$ & $\begin{array}{l}0.522^{* * *} \\
(0.193)\end{array}$ & $\begin{array}{l}0.492^{*} \\
(0.252)\end{array}$ & $\begin{array}{l}0.512^{* * *} \\
(0.186)\end{array}$ & $\begin{array}{l}0.362^{* * *} \\
(0.137)\end{array}$ \\
\hline 4 children in the household & & $\begin{array}{l}-0.419 \\
(0.400)\end{array}$ & $\begin{array}{l}-0.407 \\
(0.393)\end{array}$ & $\begin{array}{l}-0.479 \\
(0.403)\end{array}$ & $\begin{array}{c}-0.393 \\
(0.417)\end{array}$ & $\begin{array}{l}-0.324 \\
(0.334)\end{array}$ \\
\hline More than 4 children in the household & & $\begin{array}{l}-0.236 \\
(0.712)\end{array}$ & $\begin{array}{l}-0.172 \\
(0.701)\end{array}$ & $\begin{array}{l}0.475 \\
(0.959)\end{array}$ & $\begin{array}{l}-0.300 \\
(0.723)\end{array}$ & $\begin{array}{l}-0.213 \\
(0.636)\end{array}$ \\
\hline At least one parent is not Italian & & $\begin{array}{l}0.243 \\
(0.191)\end{array}$ & $\begin{array}{l}0.288 \\
(0.197)\end{array}$ & $\begin{array}{l}0.0959 \\
(0.197)\end{array}$ & $\begin{array}{l}0.243 \\
(0.191)\end{array}$ & $\begin{array}{l}0.169 \\
(0.145)\end{array}$ \\
\hline Mother university x Father university & & & & & & \\
\hline No, Yes & & $\begin{array}{l}0.582^{* *} \\
(0.253)\end{array}$ & $\begin{array}{l}0.613^{* *} \\
(0.266)\end{array}$ & $\begin{array}{l}0.622^{* *} \\
(0.292)\end{array}$ & $\begin{array}{l}0.574^{* *} \\
(0.251)\end{array}$ & $\begin{array}{l}0.380^{*} \\
(0.199)\end{array}$ \\
\hline Yes, No & & $\begin{array}{l}0.166 \\
(0.152)\end{array}$ & $\begin{array}{l}0.171 \\
(0.156)\end{array}$ & $\begin{array}{l}0.0512 \\
(0.171)\end{array}$ & $\begin{array}{l}0.174 \\
(0.153)\end{array}$ & $\begin{array}{l}0.0551 \\
(0.115)\end{array}$ \\
\hline Yes, Yes & & $\begin{array}{l}0.130 \\
(0.151)\end{array}$ & $\begin{array}{l}0.160 \\
(0.158)\end{array}$ & $\begin{array}{l}0.0546 \\
(0.185)\end{array}$ & $\begin{array}{l}0.133 \\
(0.151)\end{array}$ & $\begin{array}{l}0.0771 \\
(0.113)\end{array}$ \\
\hline Mother stop working $\mathrm{x}$ Father stop working & & & & & & \\
\hline No, Yes & & $\begin{array}{l}0.0475 \\
(0.178)\end{array}$ & $\begin{array}{l}-0.0168 \\
(0.182)\end{array}$ & $\begin{array}{l}-0.0327 \\
(0.246)\end{array}$ & $\begin{array}{l}0.0516 \\
(0.179)\end{array}$ & $\begin{array}{l}0.0607 \\
(0.137)\end{array}$ \\
\hline Yes, No & & $\begin{array}{l}0.0423 \\
(0.163)\end{array}$ & $\begin{array}{l}0.00801 \\
(0.171)\end{array}$ & $\begin{array}{l}0.191 \\
(0.201)\end{array}$ & $\begin{array}{l}0.0308 \\
(0.164)\end{array}$ & $\begin{array}{l}-0.0190 \\
(0.121)\end{array}$ \\
\hline Yes, Yes & & $\begin{array}{l}-0.0243 \\
(0.223)\end{array}$ & $\begin{array}{l}0.0170 \\
(0.232)\end{array}$ & $\begin{array}{l}0.102 \\
(0.268)\end{array}$ & $\begin{array}{l}-0.0257 \\
(0.225)\end{array}$ & $\begin{array}{l}-0.0500 \\
(0.171)\end{array}$ \\
\hline Mother switched to smart working & & $\begin{array}{l}-0.0857 \\
(0.171)\end{array}$ & $\begin{array}{l}0.0184 \\
(0.178)\end{array}$ & $\begin{array}{l}0.146 \\
(0.294)\end{array}$ & $\begin{array}{l}-0.0987 \\
(0.171)\end{array}$ & $\begin{array}{l}-0.0228 \\
(0.127)\end{array}$ \\
\hline Both parents under strict lockdown & & $\begin{array}{l}1.274^{* *} \\
(0.577)\end{array}$ & $\begin{array}{l}1.241^{* *} \\
(0.615)\end{array}$ & $\begin{array}{l}1.427^{* *} \\
(0.669)\end{array}$ & $\begin{array}{l}1.316^{* *} \\
(0.572)\end{array}$ & $\begin{array}{l}1.239^{* *} \\
(0.486)\end{array}$ \\
\hline Survey respondent is male & & $\begin{array}{l}-0.408^{*} \\
(0.230)\end{array}$ & & $\begin{array}{l}-0.140 \\
(0.342)\end{array}$ & $\begin{array}{l}-0.359 \\
(0.230)\end{array}$ & $\begin{array}{l}-0.351^{* *} \\
(0.171)\end{array}$ \\
\hline Date of interview & & $\begin{array}{l}0.0163 \\
(0.0793)\end{array}$ & $\begin{array}{l}0.0543 \\
(0.0870)\end{array}$ & $\begin{array}{l}0.0141 \\
(0.123)\end{array}$ & $\begin{array}{l}0.00521 \\
(0.0794)\end{array}$ & $\begin{array}{l}0.0158 \\
(0.0589)\end{array}$ \\
\hline Province FE & - & Yes & Yes & Yes & Yes & Yes \\
\hline Day of week FE & - & Yes & Yes & Yes & Yes & Yes \\
\hline Observations & 2796 & 2578 & 2407 & 2563 & 2576 & 2626 \\
\hline$R$-squared ${ }^{2}$ & 0.019 & 0.316 & 0.317 & 0.299 & 0.315 & 0.0810 \\
\hline
\end{tabular}

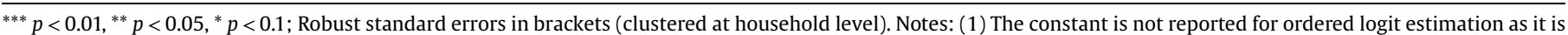

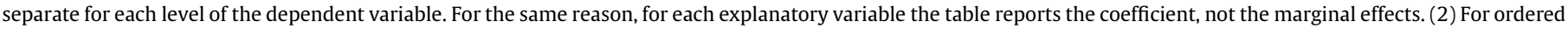
logit estimation, the pseudo $R$-squared is reported. 


\section{Appendix B. Supplementary Data}

Supplementary data associated with this article can be found, in the online version, at https://doi.org/10.1016/j.ehb.2021.101016.

\section{References}

Adams-Prassl, A., Boneva, T., Golin, M., Rauh, C., 2020. Inequality in the Impact of the Coronavirus Shock: Evidence from Real Time Surveys. IZA Discussion Papers 13183. Institute of Labor Economics (IZA).

Alon, T.M., Doepke, M., Olmstead-Rumsey, J., Tertilt, M., 2020. The Impact of COVID19 on Gender Equality. NBER Working Paper No. 26947.

Amuedo-Dorantes, C., Marcén, M., Morales, M., Sevilla, A, 2020. October COVID-19 School Closures and Parental Labor Supply in the United States. IZA Discussion Papers 13827. Institute of Labor Economics (IZA).

Andrew, A., Cattan, S., Costa-Dias, M., Farquharson, C., Kraftman, L., Krutikova, S. Phimister, A., Sevilla, A., 2020a. Learning During the Lockdown: Real-Time Data on Children's Experiences During Home Learning. IFS Briefing Note BN288. .

Andrew, A., Cattan, S., Costa Dias, M., Farquharson, C., Kraftman, L., Krutikova, S. Phimister, A., Sevilla, A., 2020b. The Gendered Division of Paid and Domestic Work under Lockdown. IZA Discussion Papers 13500. Institute of Labor Economics (IZA).

Angrist, J.D., Battistin, E., Vuri, D., 2017. In a small moment: class size and moral hazard in the Italian mezzogiorno. Am. Econ. J. Appl. Econ. 9 (4), 216-249.

Barigozzi, F., Di Timoteo, C., Monfardini, C., et al., 2020. Italian Families in the 21st Century: Gender Gaps in Time Use and Their Evolution. IZA Discussion Paper No. 13348. .

Becker, G.S., 1981. A Treatise on the Family. Harvard University Press.

Biroli, P., Bosworth, S., Della Giusta, M., Di Girolamo, A., Jaworska, S., Vollen, J., 2020. Family Life in Lockdown. IZA Discussion Papers 13398.

Bloemen, H.G., Pasqua, S., Stancanelli, E.G., 2010. An empirical analysis of the time allocation of Italian couples: are they responsive? Rev. Econ. Household 8 (3), 345-369.

Briscese, G., Lacetera, N., Macis, M., Tonin, M., 2020. Compliance with COVID-19 Social-Distancing Measures in Italy: The Role of Expectations and Duration. NBER Working Paper No. 26916. .

Brunello, G., Checchi, D., 2005. School quality and family background in Italy. Econ. Educ. Rev. 24 (5), 563-577.

Champeaux, H., Mangiavacchi, L., Piccoli, L., Marchetta, F., 2021. Learning at home: distance learning solutions and child development during the COVID-19 lockdown. CEPR Covid Econ. 68, 69-99.

Cunha, F., Heckman, J.J., Schennach, S.M., 2010. Estimating the technology of cognitive and noncognitive skill formation. Econometrica 78 (3), 883-931.
Del Boca, D., Monfardini, C., Nicoletti, C., 2017. Parental and child time investments and the cognitive development of adolescents. J. Labor Econ. 35 (2), 565-608.

Del Boca, D., Oggero, N., Profeta, P., Rossi, M., 2020. Women's Work, Housework and Childcare, Before and During COVID-19. IZA Discussion Paper No. 13409.

Engzell, P., Frey, A., Verhagen M.M., Learning inequality during the covid-19 pandemic. SocArXiv ve4z7.

Farré, L., Fawaz, Y., González, L., Graves, J., 2020. How the COVID-19 Lockdown Affected Gender Inequality in Paid and Unpaid Work in Spain. IZA Discussion Paper No. 13434.

Fiorini, M., Keane, M.P., 2014. How the allocation of children's time affects cognitive and noncognitive development. J. Labor Econ. 32 (4), 787-836.

Giménez-Nadal, J.I., Mangiavacchi, L., Piccoli, L., 2019. Keeping inequality at home: the genesis of gender roles in housework. Labour Econ. 58, 52-68.

Grewenig, E., Lergetporer, P., Werner, K., Woessmann, L., Zierow, L., et al., 2020 COVID-19 and Educational Inequality: How School Closures Affect Low-and High-Achieving Students. Technical Report. CESifo.

Harris, K.M., Furstenberg, F.F., Marmer, J.K., 1998. Paternal involvement with adolescents in intact families: the influence of fathers over the life course. Demography 35 (2), 201-216.

Hsin, A., Felfe, C., 2014. When does time matter? Maternal employment, children's time with parents, and child development. Demography 51 (5), 1867-1894.

Hupkau, C., Petrongolo, B., 2020. May Work, Care and Gender During the COVID-19 Crisis. CEP COVID-19 Briefings cepcovid-19-002. Centre for Economic Performance, LSE.

Jaume, D., Willén, A., 2019. The long-run effects of teacher strikes: evidence from Argentina. J. Labor Econ. 37 (4), 1097-1139.

Mancini, A.L., Monfardini, C., Pasqua, S., 2017. Is a good example the best sermon? children's imitation of parental reading. Rev. Econ. Household 15 (3), 965-993.

Mangiavacchi, L., Piccoli, L., 2018. Parental alcohol consumption and adult children's educational attainment. Econ. Hum. Biol. 28, 132-145.

Mencarini, L., Pasqua, S., Romiti, A., 2019. Single-mother families and the gender gap in children's time investment and non-cognitive skills. Rev. Econ. Household 17 (1), 149-176.

Moroni, G., Nicoletti, C., Tominey, E., 2019. Child Socio-Emotional Skills: The Role of Parental Inputs, IZA Discussion Paper No. 12432.

Moroni, G., Nicoletti, C., Tominey, E., 2020. Children's Socio-Emotional Skills and the Home Environment During the COVID-19 Crisis. VoxEU.org. CEPR.

Pieroni, L., Lanari, D., 2018. The role of fathers in the criminal careers of juveniles in Italy. J. Demogr. Econ. 84 (4), 419-445.

Pischke, J.-S., 2007. The impact of length of the school year on student performance and earnings: evidence from the German short school years. Econ. J. 117 (523), 1216-1242.

Sevilla, A., Smith, S., 2020. Baby Steps: The Gender Division of Childcare During the COVID-19 Pandemic. IZA Discussion Paper No. 13302. . 